\title{
Molluscan Diversity Influenced by Mangrove Habitat in the Khors of Qatar
}

\author{
Jassim A. Al-Khayat ${ }^{1} \cdot$ P. Vethamony ${ }^{1} \cdot$ Mandar Nanajkar $^{2}$
}

Received: 18 July 2020 / Accepted: 11 March 2021 / Published online: 29 March 2021

(C) The Author(s) 2021

\begin{abstract}
The Exclusive Economic Zone (EEZ) of Qatar is a rapidly developing region within the Arabian Gulf, where monitoring of changes in benthic biodiversity and its functioning is needed. The influence of mangroves and seasonality on the nearshore subtidal molluscan diversity at three distinct khors (nearshore tidal bays) - natural mangroves (Al Dhakhira), planted mangroves (Al Mafyar) and no-mangroves (Dawhat Zekreet) - are investigated in this study. This study concludes that even the sub-tidal area is influenced by mangroves, and mangroves increase the diversity of molluscs compared to the site that lacks mangroves. The maximum salinity (59.8 psu) was observed at Dawhat Zekreet during summer, and the minimum (41.44 psu) at Al Dhakhira in winter. Chlorophyll a level was low for all the khors, and rarely exceeded $1 \mu \mathrm{g} / \mathrm{L}$, depicting oligotrophic waters. Al Dhakhira demonstrated the highest molluscan species richness (32), and shared 28 species in common with Al Mafyar. Dawhat Zekreet had the fewest mollusc species number and no mangroves. When cumulative diversity over all seasons was considered, Dawhat Zekreet exhibited the lowest species richness; Al Dhakhira, the highest. Some mangrove regions have been already utilized for developmental activities, and Qatar needs to continue the program of mangrove conservation as a vital habitat for molluscs.
\end{abstract}

Keywords Molluscan diversity $\cdot$ Mangrove habitat $\cdot$ High saline water $\cdot$ Nearshore tidal bays (Khors) of Qatar

\section{Introduction}

The distribution and dynamics of benthic communities are important to the health of any ecosystem and differ between pristine and perturbed ecosystems. In recent years, coastal regions are constantly under pressure due to unabated anthropogenic intervention (Törnroos et al. 2015), and the Arabian Gulf is no exception. The Gulf region is one of the most rapidly developing areas with oil and gas exploration being the main industry-driven activity (Van Lavieren et al. 2011). Therefore, it is important to know the coastal ecosystem for understanding the environmental status in the wake of development and rapid expansion of human endeavours (Van Lavieren et al. 2011). Molluscan diversity helps to assess the effect of environmental impacts on benthic ecosystem

Jassim A. Al-Khayat

jalkhayat@qu.edu.qa

1 Environmental Science Center, Qatar University, P.O. Box 2713, Doha, Qatar

2 CSIR-National Institute of Oceanography, Dona Paula, Goa 403 004, India functioning, and molluscs serve as an important food resource. The Exclusive Economic Zone (EEZ) of Qatar supports diverse marine resources such as corals, fisheries, extensive seagrass meadows, mangrove swamps, oyster beds, shrimps and sponge beds. The nearshore tidal bays, locally known as "khors", existing around the Qatar peninsula provide a unique habitat for benthic fauna.

In Qatar, natural and planted mangrove swamps can be found in sheltered muddy bays, lagoons and fringing tidal creeks (khors). The analysis of past data available to us shows that the mangrove swamps cover approximately 1178 ha of the coastal area of Qatar (Table 1) and it ranges from areas with only sparse cover by small shrubs such as the Dawhat Zekreet site to dense swamps with some trees exceeding $5 \mathrm{~m}$ in height such as the Al Dhakhira site. The natural swamps, composed of well-developed tres of 2-5 m, can be found on the eastern coast at Al-Dhakhira ( 545 ha - supposed to be the oldest and the best established) and at Al-Khor (117 ha). The planted one, with more dispersed trees from 1 to $4 \mathrm{~m}$ height, is found in groups on the northern and western coasts, mainly at Al- Mafyar (78.4 ha), Fuwairit (12.5 ha), Simaisma (1.5 ha), and Dawhat Zekreet (1.1 ha) (Al-Khayat and Balakrishnan 2014). The mangroves were planted during the 1980 s by 
Table 1 Mangrove areas around Qatar

\begin{tabular}{lllll}
\hline Site & Mangrove swamp status & Year of plantation & Location & Area (ha) \\
\hline Al Khor & Natural & - & East & 116.9 \\
Al Dhakhira & Natural & - & East & 545.8 \\
Simaisma & Planted & 1983 & East & 1.4 \\
Al Wusail & Planted & 1989 & East & 8.6 \\
Umm Al Hul & Planted & 1980 & South & 30.6 \\
Al Wakra & Planted & ${ }^{a} 1980$ & South & 13.1 \\
Ras Laffan & Planted & 1993 & Northeast & 18.0 \\
Al Jassasia & Planted & 1981 & Northeast & 6.0 \\
Fuwairit & Planted & 1981 & North & 12.5 \\
Al Mafyar & Planted & 1981 & North & 78.4 \\
Al Ruwais & Planted & ${ }^{\mathrm{a}} 1981$ & North & 80.4 \\
Abu Dhalouf & Planted & 1989 & North & 21.7 \\
Al Arish & Planted & 1989 & Northwest & 3.3 \\
Al Zubara & Planted & 1989 & Northwest & 1.5 \\
Al Suwaihliya & Planted & 1989 & West & 8.6 \\
Dawhat Zekreet & Planted & ${ }^{b} 1981 \& 1990$ & West & 1.1 \\
Other areas & Planted & 1983 & + & 230.4 \\
TOTAL & & & & $\mathbf{1 1 7 8 . 3}$ \\
\hline
\end{tabular}

${ }^{\mathrm{a}}$ Mostly removed for coastal development; ${ }^{\mathrm{b}}$ Very low growth and used to feed camels + different locations around Qatar peninsula scholars, students, organizations, and the Qatar Environment and Agricultural Ministry. They were planted in areas where mangroves were not found before (El-Ghazaly and AbdelRazik 1993; Al-Khayat 2010). The natural mangroves are spread in areas where fresh ground water is said to seep out (El-Ghazaly and Abdel-Razik 1993).

Structurally complex habitats such as seagrasses, marshes, and mangroves are known to support higher densities and diversity of benthic organisms as compared to non-vegetated areas (Edgar 1990). The complex architecture of coastal habitats provides a high number of settlement sites and enhanced nutrients, as well as lower predation pressure (Davis et al. 2001). The gastropods due to their predatory nature, occupy a central role in maintaining the functioning and productivity of mangroves through by removing the encrusting fauna like barnacles and oysters from the mangrove roots (Shanmugam and Vairamani 1999). For example, Thais sp. may feed on barnacles encrusted on mangrove roots, and predation pressure by these snails may positively influence mangrove root growth by cleaning the aerial root system (Koch and Wolff 1996). The macro-invertebrates in the Arabian Gulf are characterized by high biodiversity, yet they are distinguished by low species richness due to harsh environmental conditions, such as high salinity and temperature (Al-Yamani et al. 2009; Basson et al. 1977; Price 2002; Sheppard et al. 2010). Anthropogenic effects likely affect the biodiversity and abundance of macro- invertebrates inhabiting the naturally stressed marine environment of the Arabian Gulf, which is considered as one of the most anthropogenically impacted regions in the world (Halpern et al. 2008). Biotic and abiotic interactions have profound impacts on the diverse benthic fauna of tropical mangroves (Satheeshkumar and Khan 2012). Salinity exceeds 43 psu and may reach 70-80 psu in tidal pools and lagoons. Marine organisms in the Arabian Gulf are living close to the limits of their environmental tolerance (Price et al. 1993).

There are several studies on marine benthic communities in the Arabian Gulf, particularly those of the intertidal coastal areas of Saudi Arabia, Kuwait, Bahrain, and United Arab Emirates (UAE) (Smythe 1972; Basson et al. 1977; Smythe 1979; McCain 1984a; McCain 1984b; Jones 1986; Jones and Richmond 1992; Kohan et al. 2012). The general features of the intertidal and subtidal macrobenthic fauna of western and northern Gulf are well documented (Jones and Richmond 1992; Kohan et al. 2012). It is reported that marine molluscs of the UAE are of Indo-Pacific origin, and their diversity is restricted by extremes of air and seawater temperature and salinity (Basson et al. 1977; Bosch et al. 1995).

There are a few studies on macroinvertebrates in the subtidal areas along the northeast coast of Qatar, but no major studies on the molluscan diversity and its seasonal changes in recent years. Benthic macrofaunal studies from the subtidal area revealed 52 species, of which crustaceans were the most diverse group with 19 species (Al-Khayat 2005). Mangroves are foundation species, which provide habitat for several invertebrates, including molluscs. Molluscs are good indicators of environmental health due to their sedentary nature (Elder 
and Collins 1991; Bresler et al. 2003; Carroll et al. 2009) and thus are widely known to show community level changes in response to anthropogenic perturbations in different habitats (Parker et al. 2013; Chakraborty et al. 2016; Chakraborty 2017). In Qatar, mangrove vegetation is sparse and mixed with salt marsh frontier vegetation along the northern and eastern coasts of Qatar. Mangroves are represented by only one native species, Avicennia marina. Some areas along the Qatar coast have natural mangrove vegetation and a few areas have been restored by plantation since 1981 (Al-Khayat and Jones 1999). Al-Khayat et al. (2019) compared the macrofaunal community of planted mangroves with that of natural mangroves. After three decades of afforestation, planted mangrove molluscs attained species diversity comparable to that found in natural mangroves.

There are several articles dealing with the taxonomy of molluscs in this region (Anbiah 2007; Bosch et al. 1995; Feulner and Hornby 2006; Smythe 1982; Morris and Morris 1993). The check-lists of molluscan fauna from the western and the eastern coasts of Qatar peninsula have been prepared by Mohammed and Al-Khayat (1994) and Al-Khayat (1997). The macro-invertebrates in the sub-tidal area along the northeast coast of Qatar have been studied by Al-Khayat and AlKhayat (2000) and Al-Khayat (2005), since then there are no major studies on the molluscan diversity its seasonal changes in the near-shore waters of Qatar. A few studies examined the effects of mangrove loss on benthic and epibenthic animals (e.g. Levings et al. 1994), but very few studies investigated how smaller-scale modification in habitat affects the biodiversity and abundance of mangrove-associated fauna (Hatcher et al. 1989).

The high molluscan diversity in mangroves is mainly due to availability of a diverse range of microhabitats (Kabir et al. 2014). The distribution and diversity of molluscs depends on several physico-chemical factors, but the underlying factor is the habitat wherein they thrive. We hypothesize that mangroves have a significant influence on the distribution and diversity of the molluscan community in the coastal habitats. The present study aims at investigating the influence of mangroves and seasonality on the subtidal molluscan diversity at three sites, having natural vegetation, planted vegetation or no-vegetation.

\section{Materials and Methods}

\section{Study Area}

The Arabian Gulf, oriented northwest to southeast, is about $1000 \mathrm{~km}$ in length; width varies from $\approx 55$ to $335 \mathrm{~km}$; average water depth is $\approx 35 \mathrm{~m}$. The seawater characteristics, especially temperature and salinity, vary along the axis of the Gulf, both in space and time. The salinity and temperature in the waters of Qatar are high due to shallow depths and no freshwater inflow from the land or precipitation. Extremely dry climate with lack of moisture in the region generates excess of evaporation over precipitation (Privett 1959; Prasad et al. 2001; Johns et al. 2003). This leads to the formation of relatively highly saline and dense water in the Arabian Gulf compared to the Sea of Oman, which impacts density-driven circulation, seasonal inflow and outflow magnitude at the Strait of Hormuz (Emery 1956; Swift and Bower 2003; Pous et al. 2015). Most of the Qatar coast consists of either sandy or mixed sandy/rocky habitat with unstable and coarse sand, which regularly moves across areas of exposed beach rock.

Sampling was carried out at twelve stations, four stations in each site (Fig. 1a). Al Dhakhira is a natural mangrove swamp site, located on the east coast, and it harbours one of the most important mangroves stands of the Gulf region. Al Mafyar site is located on the north coast, and it harbours planted mangrove A. marina. Thirty-nine years have passed since the cultivation at Al Mafyar, and it is quite successful. So far, the mangrove swamps are not destroyed. Mangroves were grown from nurseries. During the 1980s, mangroves (A. marina), which had grown naturally around Al Khor (adjacent to Al Dhakhira) and Al Dhakhira, were taken and planted at a few select coastal regions. Today, they have become a mangrove swamp habitat and have an integrated ecosystem, which is one of the highly productive areas in the marine environment of Qatar along with coral reef communities and seagrass beds. The areas from which mangroves were removed, have not been replanted as economic or recreational projects have come into existence there (for example, tourist boat ports, corniches, traditional markets, parks, and places of entertainment). Mangroves at the study areas are visible on the Google Earth satellite photos for the years 2009 and 2020 (Fig. 1b). Dawhat Zekreet (highly saline and a no-mangrove area) is an important fishery ground on the west coast of Qatar peninsula. Water and benthic fauna samples were collected from the above three sites during January 2009, April 2009, August 2009, and October 2009, representing the four seasons- winter, spring, summer and autumn, respectively. The water depth was $1.0 \mathrm{~m}$ in all the stations, except at stations 2 and 3, where it was $2 \mathrm{~m}$ and $1.5 \mathrm{~m}$, respectively.

\section{Sampling and Methodology}

Air and seawater temperature, dissolved oxygen, and hydrogen ion concentration $(\mathrm{pH})$ were measured using a Waterproof Hand-held pH/Dissolved Oxygen/Temperature Meter, PD 300, and salinity was measured using a refractometer (VEE GEE Model STX-3). For the determination of Chlorophyll a (phytoplankton biomass indicator), one litre of seawater was filtered and analysed using a spectrophotometer, following the method of Parsons et al. (1984). 
a
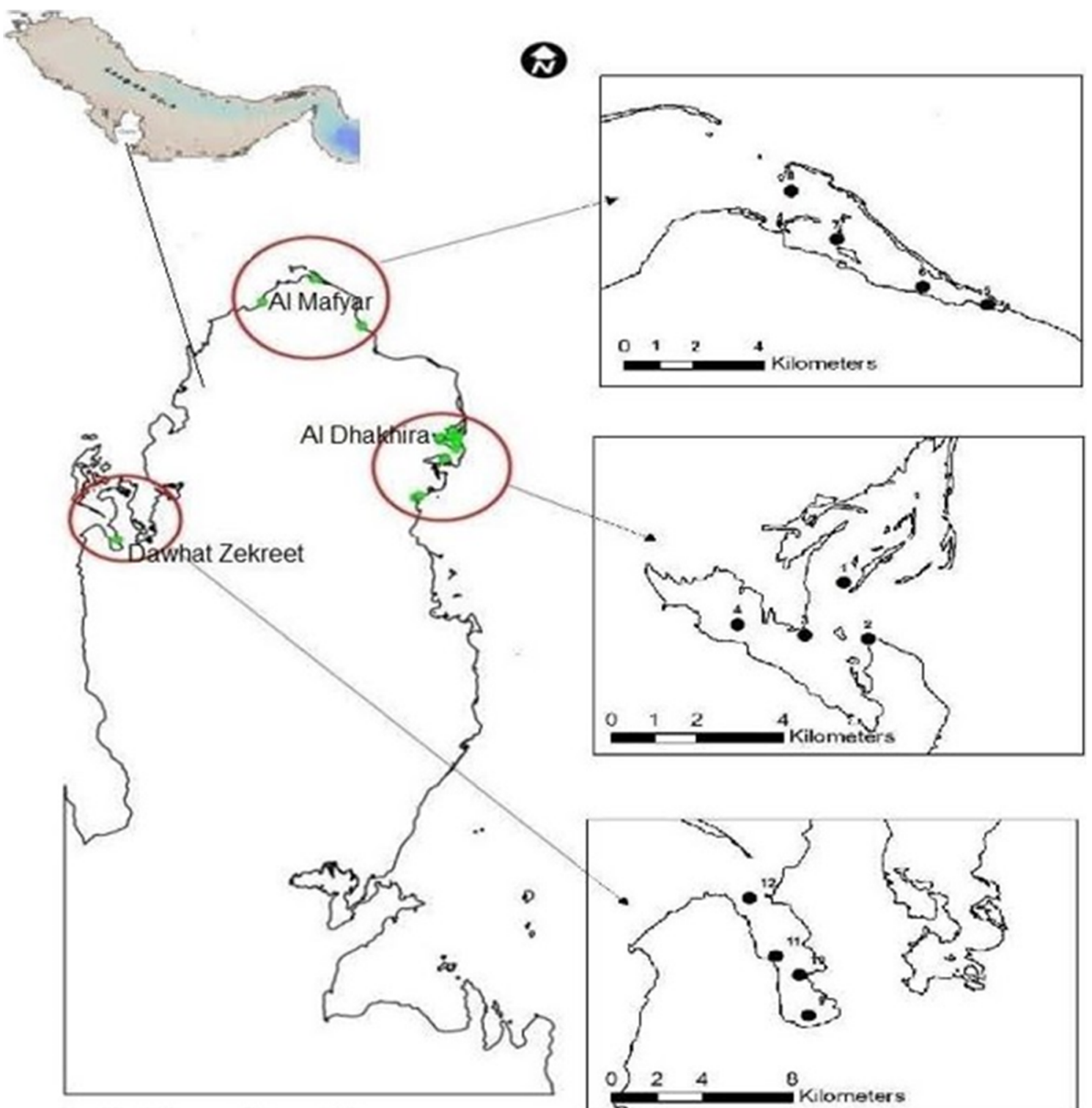

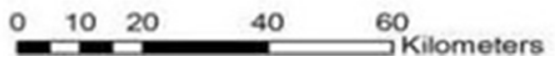

Fig. 1 a Map of study area and sampling locations around Qatar peninsula: Al Dhakhira (mangrove stations: 1, 2, 3 and 4), Al Mafyar (planted mangrove stations: 5, 6, 7 and 8) and Dawhat Zekreet (high saline and no-mangrove stations: 9,10,11 and 12). Arabian Gulf is given

Macrobenthic sampling was carried out using snorkelling. Macrobenthic fauna samples were collected from the stations using a $1.0 \mathrm{~m}^{2}$ metal frame quadrate. Molluscs dwelling in the top $10 \mathrm{~cm}$ of the sediment were collected along with the sediments, and were stored in labelled polyethlene bags. The sediment collected from the quadrate was sieved through $0.5 \mathrm{~mm}$ mesh. Triplicate samples from each station were pooled to avoid the effects of selectivity by sample and species aggregations (Towns 1979). Benthic organisms were sorted out and identified with reference to appropriate keys and in inset with Qatar circled in red. b Mangrove cover during 2009 (sampling year) and 2020 at (i) Al Dhakhira, (ii) Al Mafyar and (iii) Dawhat Zekreet and station locations in these sites

works of Jones (1986), Vine (1986), Bosch and Bosch (1989), Oliver (1992), Green (1994) and Bosch et al. (1995).

Shannon-Wiener Species richness, species diversity, and species evenness were calculated according to ShannonWiener function (Shannon and Wiener 1963) using the abundance (no. of species/unit area) of each species at each site. Simpson diversity and Shannon index score abundance differently for each species at each location. Simpson diversity gives importance to dominant species and it is a measure of dominance (higher the value, lower the diversity). Shannon 


\section{b}
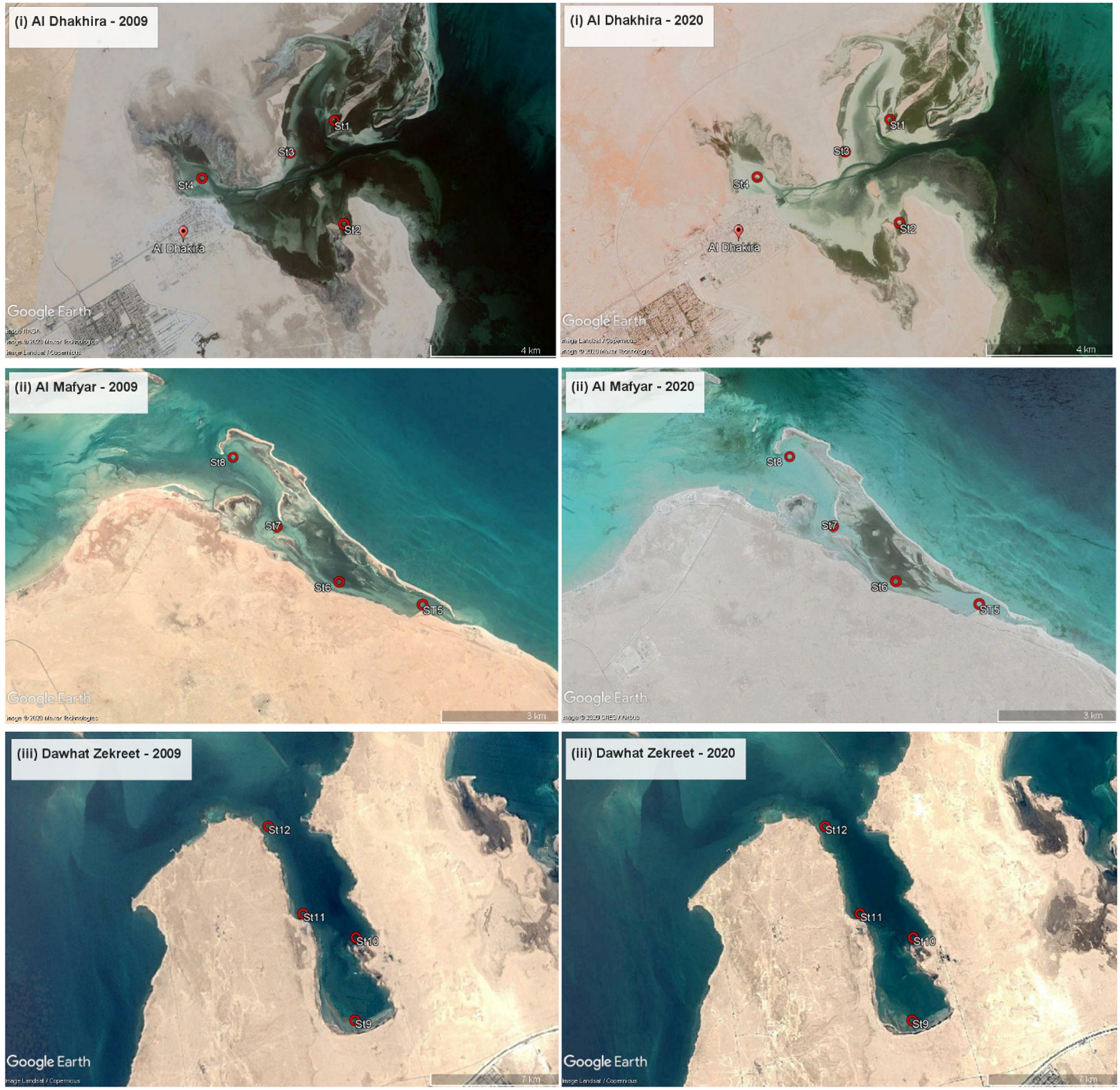

Fig. 1 (continued)

index considers rarity of species and it is sensitive to it (higher the value, higher the diversity). Analysis of variance has been performed using the general linear model of Minitab (Minitab 17 Statistical Software) to find the variability of temperature, salinity, and species. Tukey's pairwise comparison was carried out to further ascertain the response of variables (temperature, salinity, and species) to location and season using means of variables that are significantly different from the rest. Similarity percentage (SIMPER) analysis was carried out to assess the cumulative contribution of species for the dissimilarity between the two sites.

\section{Results}

\section{Physico-Chemical Parameters}

All the hydrochemical parameters for all seasons and stations are presented in Fig. 2. The means of hydro-chemical parameters measured at 12 stations during 4 seasons are provided in Table 2. The maximum sea surface temperature (SST), $33.2^{\circ} \mathrm{C}-35.0^{\circ} \mathrm{C}$ was recorded at Al Mafyar (station 9) during summer, and the minimum $\left(20.12{ }^{\circ} \mathrm{C}-22.62{ }^{\circ} \mathrm{C}\right)$ at Dawhat Zekreet (station 9) in winter. While, salinity was as high as 
Table 2 Overall mean of hydrochemical, DO and Chlorophyll a concentrations of all seasons for the different stations

\begin{tabular}{|c|c|c|c|c|c|c|c|c|}
\hline Areas & Stations & Lat. $\left({ }^{\circ} \mathrm{N}\right)$ & Long. $\left({ }^{\circ} \mathrm{E}\right)$ & Temp. $\left({ }^{\circ} \mathrm{C}\right)$ & Salinity & $\mathbf{p H}$ & DO $(\mathrm{mg} / \mathrm{L})$ & Chl. $a(\mu \mathrm{g} / \mathrm{L})$ \\
\hline \multirow[t]{4}{*}{ Al Dhakhira (Natural mangroves) } & 1 & 25.7555 & 51.5735 & $29.1 \pm 1.9$ & $43.4 \pm 0.6$ & $8.2 \pm 0.03$ & $5.5 \pm 0.50$ & $0.43 \pm 0.1$ \\
\hline & 2 & 25.7338 & 51.5754 & $29.1 \pm 2.0$ & $43.8 \pm 0.8$ & $8.2 \pm 0.01$ & $5.7 \pm 0.25$ & $0.69 \pm 0.2$ \\
\hline & 3 & 25.7484 & 51.5636 & $29.2 \pm 2.2$ & $43.7 \pm 0.7$ & $8.2 \pm 0.01$ & $6.02 \pm 0.3$ & $0.61 \pm 0.1$ \\
\hline & 4 & 25.7430 & 51.5444 & $28.9 \pm 2.0$ & $43.9 \pm 0.7$ & $8.2 \pm 0.01$ & $5.83 \pm 0.4$ & $0.56 \pm 0.2$ \\
\hline \multirow[t]{4}{*}{ Al Mafyar (Planted mangroves - 1981) } & 5 & 26.1387 & 51.2951 & $29.3 \pm 2.4$ & $44.3 \pm 0.7$ & $8.2 \pm 0.03$ & $5.42 \pm 0.2$ & $0.3 \pm 0.03$ \\
\hline & 6 & 26.1422 & 51.2812 & $29.8 \pm 2.4$ & $43.8 \pm 0.5$ & $8.3 \pm 0.02$ & $5.49 \pm 0.3$ & $0.35 \pm 0.1$ \\
\hline & 7 & 26.1510 & 51.2704 & $29.6 \pm 2.3$ & $43.6 \pm 0.6$ & $8.3 \pm 0.03$ & $5.7 \pm 0.14$ & $0.39 \pm 0.1$ \\
\hline & 8 & 26.1631 & 51.2621 & $29.7 \pm 2.3$ & $43.2 \pm 0.4$ & $8.2 \pm 0.04$ & $5.9 \pm 0.12$ & $0.34 \pm 0.1$ \\
\hline \multirow[t]{4}{*}{ Dawhat Zekreet (No mangroves) } & 9 & 25.4652 & 50.8361 & $29.2 \pm 2.8$ & $56.8 \pm 1.8$ & $8.2 \pm 0.09$ & $5.3 \pm 0.13$ & $0.38 \pm 0.1$ \\
\hline & 10 & 25.4912 & 50.8366 & $29.4 \pm 2.6$ & $56.3 \pm 1.6$ & $8.3 \pm 0.03$ & $5.47 \pm 0.2$ & $0.48 \pm 0.1$ \\
\hline & 11 & 25.4988 & 50.8179 & $29.3 \pm 2.6$ & $55.2 \pm 1.4$ & $8.2 \pm 0.06$ & $5.34 \pm 0.2$ & $0.40 \pm 0.1$ \\
\hline & 12 & 25.5268 & 50.8054 & $29.1 \pm 2.7$ & $54.9 \pm 1.2$ & $8.2 \pm 0.04$ & $5.07 \pm 0.3$ & $0.3 \pm 0.03$ \\
\hline
\end{tabular}

59.8 psu at Dawhat Zekreet (station 9) during summer, it was the lowest (41.44 psu) at Al Dhakhira (station 2) in winter. Dissolved oxygen (DO) ranged between 4.32 and $6.40 \mathrm{mg} / \mathrm{L}$, with the highest value recorded in winter at station 3 , followed by station $2(6.31 \mathrm{mg} / \mathrm{L})$. Variation in $\mathrm{pH}$ was not significant among the different stations - the highest $\mathrm{pH}$ (8.37) was recorded in summer (at station 9), with the lowest (8.02) during autumn at station 11. Chlorophyll a levels were low for all nearshore bays, and rarely exceeded $1 \mu \mathrm{g} / \mathrm{L}$; hence, the study areas are classified as oligotrophic (Quigg et al. 2013). The highest levels were recorded off Al Dhakhira at 2 stations with $1.121 \mu \mathrm{g} / \mathrm{L}$ and $1.122 \mu \mathrm{g} / \mathrm{L}$, respectively.

\section{Species Composition and Distribution}

A total of 2370 organisms belonging to Gastropoda, Scaphopoda, and Bivalvia classes, representing 36 families were reported from the study area (Table 3). Among the three classes encountered, Gastropoda were the dominant group at all the three sites. Gastropoda were represented by 65 species, belonging to 23 families. Bivalvia ranked second in abundance with 46 species and 11 families. Scaphopoda had the lowest abundance represented by 4 species belonging to 2 families. In Table 3, the totals of rows and columns, represent the species present. The row totals represent the particular species present in all the 12 stations, and the column totals represent all the species present in the particular station.

\section{Species Abundance - Seasonal and Spatial}

During winter, the gastropods were dominant at Al Dhakhira represented by 16 species, while gastropod diversity was the lowest at Al Mafyar (2 species only). Among the gastropods, Mitrella blanda was the most common species, and it was represented by 8 individuals $/ \mathrm{m}^{2}$ at Al Dhakhira, followed by
Cerithium sp. (6 individuals $/ \mathrm{m}^{2}$ ) at Dawhat Zekreet; other species were represented by 2 to 4 individuals $/ \mathrm{m}^{2}$. Bivalves were the most diverse at Al Mafyar with 10 species, while other sites were represented by 2 to 4 species only. Of these, Diplodonta sp. was represented by 6 individuals $/ \mathrm{m}^{2}$ at $\mathrm{Al}$ Mafyar, Tellina sp. by 6 individuals $/ \mathrm{m}^{2}$ at Al Mafyar and Dawhat Zekreet, and other bivalve species were represented by 2 to 4 individuals $/ \mathrm{m}^{2}$. Scaphopods Dentalium tomlini were represented by 2 individuals $/ \mathrm{m}^{2}$, Dentalium sp. by 2 individuals $/ \mathrm{m}^{2}$, and Laevidentalium curvotracheatum by 2 individuals $/ \mathrm{m}^{2}$ at $\mathrm{Al}$ Dhakhira.

In spring, the maximum number of gastropods (15 species) was recorded at Al Dhakhira, and the lowest at Al Mafyar (1 species). Of these, Cerithium sp. was represented by 30 and 32 individuals $/ \mathrm{m}^{2}$, respectively at two stations in Al Dhakhira. Umbonium vestiarium was represented by 28 individuals $/ \mathrm{m}^{2}$ at Al Mafyar. Scaphopods were most diverse at Al Dhakhira in two stations with 2 species each and least diverse at one station in Al Dhakhira and two stations in Dawhat Zekreet with 1 species, while they were absent from other stations (Fig. 3). L. curvotracheatum was represented by 6 individuals $/ \mathrm{m}^{2}$ at Al Dhakhira. The highest diversity of bivalves (9 species) as well as the lowest ( 2 species) were recorded at 2 stations at Al Mafyar (Fig. 3; Table 3). Of these, Callista florida was represented by 20 individuals $/ \mathrm{m}^{2}$ at Al Mafyar. Each of the species Divalinga arabica, Acrosterigma maculosum, Carditopsis majeeda, and Tellinella sp. was represented by 16 individuals $/ \mathrm{m}^{2}$ at $\mathrm{Al}$ Mafyar (Fig. 3; Table 3).

During summer season, the highest number of gastropod species was recorded at Dawhat Zekreet with 11 species and the lowest at Al Dhakhira with 2 species (Table 3). Of these, Perinella cingulata was represented by 40 individuals $/ \mathrm{m}^{2}$ at Al Dhakhira, Cerithium rueppelli by 24 individuals $/ \mathrm{m}^{2}$ at Dawhat Zekreet and Cerithium scabridum by 16 individuals/ $\mathrm{m}^{2}$ at Al Dhakhira, while Cerithium sp. was represented by 20 
Fig. 2 a Chlorophyll a concentration off Al Dhakhira, Al Mafyar and Dawhat Zekreet during winter, spring, summer, and autumn of 2009; value of each colour bar is the average of Chlorophyll a of 4 stations at each area; error bar represents mean deviation of Chlorophyll a $(\mu \mathrm{g} / \mathrm{L})$. b Seawater temperature $\left({ }^{\circ} \mathrm{C}\right)$ and Salinity (psu) off Al Dhakhira, Al Mafyar and Dawhat Zekreet during winter, spring, summer, and autumn of 2009; value of each colour bar is the average of specific parameter at 4 stations in each location
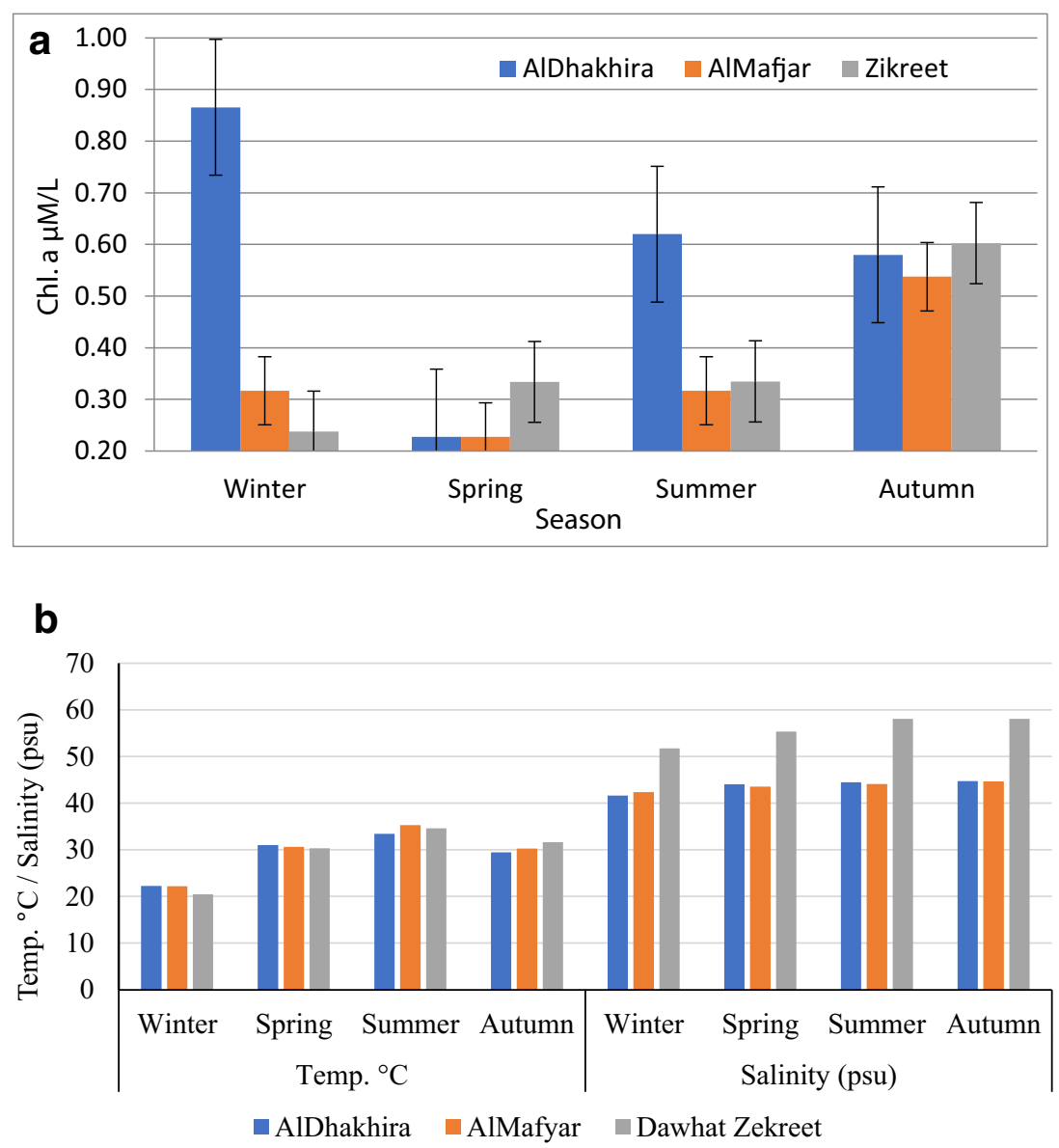

individuals $/ \mathrm{m}^{2}$ at Al Dhakhira. Mitrella blanda was common in most of the stations, and it was represented by 16 individuals/ $\mathrm{m}^{2}$ at Al Mafyar. The highest number of scaphopods was recorded at Al Dhakhira with 2 species, while they were absent in other areas. The highest number of bivalves was recorded at Al Mafyar with 11 species, while they were in the range of 0 to 5 species at other areas (Fig. 3; Table 3). Fulvia australis and Fulvia fragile were represented by 12 individuals $/ \mathrm{m}^{2}$ at $\mathrm{Al}$ Mafyar, and Diplodonta sp. was represented by 20 individuals $/ \mathrm{m}^{2}$ at the same area. The other bivalve species were represented by 2 to 10 individuals $/ \mathrm{m}^{2}$ at other areas (Fig. 3).

During autumn season, the highest number of gastropods species was recorded at Al Dhakhira with 10 species, and the lowest at Dawhat Zekreet with 2 species, while they were absent at Al Mafyar. Cerithium scabridum was represented by 40 individuals $/ \mathrm{m}^{2}$ at Dawhat Zekreet, while it fluctuated between 4 and 8 at other areas (Table 3). P. cingulata was represented by 24 individuals $/ \mathrm{m}^{2}$ at Al Dhakhira and M. blanda was represented by 22 individuals $/ \mathrm{m}^{2}$ at $\mathrm{Al}$ Mafyar. Scaphopods were recorded only at a station in $\mathrm{Al}$ Dhakhira with 1 species (2 individuals $/ \mathrm{m}^{2}$ ).

Overall, the highest number of gastropods was recorded at a station in Al Dhakhira with 32 species, and the lowest number of gastropods was recorded at a station in Al Mafyar with
6 species. Scaphopods were recorded in the range of 2-4 species at Al Dhakhira, and the lowest at Dawhat Zekreet with 1 species. The number of bivalves recorded was in the range of 3-25. C. scabridum, Cerithium sp., M. blanda, and Mitrella sp. were most dominant at most of the stations, except at a station in Al Mafyar. Dentalium octangulatum and Dentalium tomlini were present only at Al Dhakhira. L. curvotracheatum was represented at Al Dhakhira and Dawhat Zekreet. The most common bivalves were Diplodonta sp., Carditopsis majeeda, and Tellina sp. (Table 3).

Figure 4 presents the season-wise percentage of each class at the sites. For example, in winter at the natural mangrove site (Al Dhakhira) there were 82 individuals belonging to the 3 classes (Gastropods, Bivalves, and Scaphopods) with 50 gastropods (therefore, we get the abundance of gastropods as $60.98 \%$ ). For this calculation, we used the original raw data (not provided in Table 3). The total species richness common to all the three sites was 19 (Fig. 5).

Table 4 shows Tukey's pairwise comparison that presents the response of the variables, namely, temperature, salinity, and species to location/season and season-location. When we refer to the results of statistical analysis (Table 4), we find that temperature was not significantly different during summer and autumn (sharing the same index 'b'), but, significantly 
Table 3 List of mollusca community collected fr om Al Dhakhira (Stations 1-4), Al Mafyar (Stations 5-8) and Dawhat Zekreet (Stations 9-12) Around Qatar peninsula. * indicates species present

\begin{tabular}{lllllllllllllllllll}
\hline Species Station & 1 & 2 & 3 & 4 & 5 & 6 & 7 & 8 & 9 & 10 & 11 & 12 & Total \\
\hline
\end{tabular}

\section{Gastropoda}

Family Fissurellidae

Diodora sp.

Family Phasianellidae

Phasianella solida (Born, 1778)

Phasianella sp.

Tricolia ios Robertson, 1985

Family Neritidae

Smaragdia souverbiana (Souverbie \& Montrouzier, 1863)

Family Trochidae

Gibbula sp.

Osilinus sp.

Trochus kotschyi Philippi, 1849

Putzevsia wiseri (Calcara, 1842)

Trochus radiatus Gmelin, 1791

Trochus sp.

Umbonium vestiarium (Linnaeus, 1758)

Umbonium sp.

Priotrochus obscurus (Wood, 1828)

Pseudominolia gradata (Sowerby III, 1895)

Pseudominolia nedyma (Melvill, 1897)

Pseudominolia sp.

Family Turritellidae

Turritella columnaris Kiener, 1843

Turritella fultoni Melvill, 1897

Turbonilla sp.

Family Littorinidae

Littoraria coccinea glabrata (Phillippi, 1846)

Littoraria sp.

Family Planaxidae

Planaxis sulcatus (Born, 1778)

Family Cerithiidae

Cerithium caeruleume Sowerby II, 1855

Pirenella cingulata (Gmelin, 1791)

Cerithium rueppelli Philippi, 1848

Cerithum scabridum Philippi, 1848

Cerithum sp.

Clypeomorus bifasciatus persicus Houbric, 1985

Clypeomorus bifasciata bifasciata (Sowerby II, 1855)

Clypeomorus sp.

Rhinoclavis sp.

Family Potamididae

Pirenella conica (Blainville, 1829)

Potamidea sp.

Family Vermetidae

Vermetus sp.

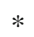

*

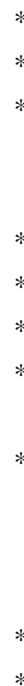

Family Crepidulidae

Calyptraea sp.
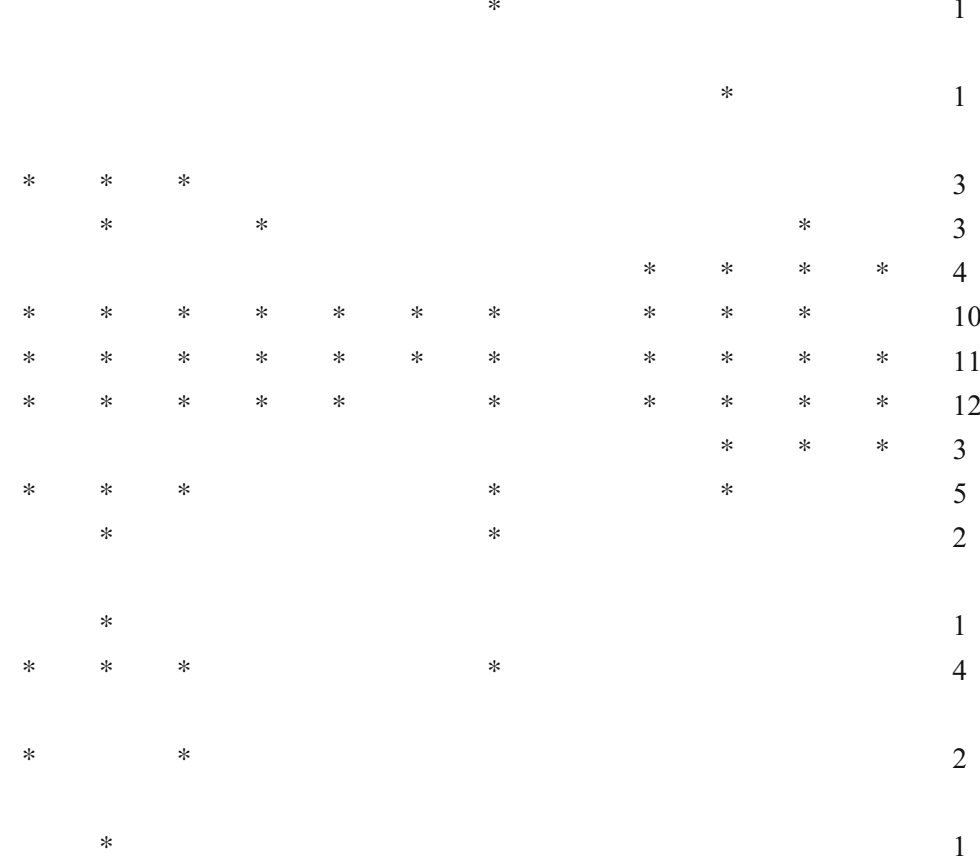
Table 3 (continued)

Species Station

$\begin{array}{lllllllllllll}1 & 2 & 3 & 4 & 5 & 6 & 7 & 8 & 9 & 10 & 11 & 12 & \text { Total }\end{array}$

Family Epitoniidae

Cirsotrema fimbriolatum (Melvill, 1897)

Family Muricidae

Hexaplex kuesterianus (Canefri, 1875)

Hexaplex rileyi D'Attilio and Myers, 1984

Hexaplex sp.

Murex sp.

Semiricinula tissoti (Saussaye, 1852)

Semiricinula konkanensis (Melvill, 1893)

Maculotriton sp.

Mitrella agatha (Melvill, 1904)

Mitrella blanda (Sowerby, 1844)

Mitrella sp.

Family Nassariidae

Nassarius arcularia plicatus (Röding, 1798)

Nassarius conoidalis (Deshayes, 1833)

Nassarius (Plicarcularia) persicus (Martens, 1874)

Nassarius sp.

Family Marginellidae

Gibberula sp.

Family Olividae

Ancilla boschi Kilburn, 1980

Ancilla farsiana Kilburn, 1981

Ancilla sp.

Family Terebridae

Hastula nana (Deshayes. 1859)

Family Bullidae

$* \quad *$
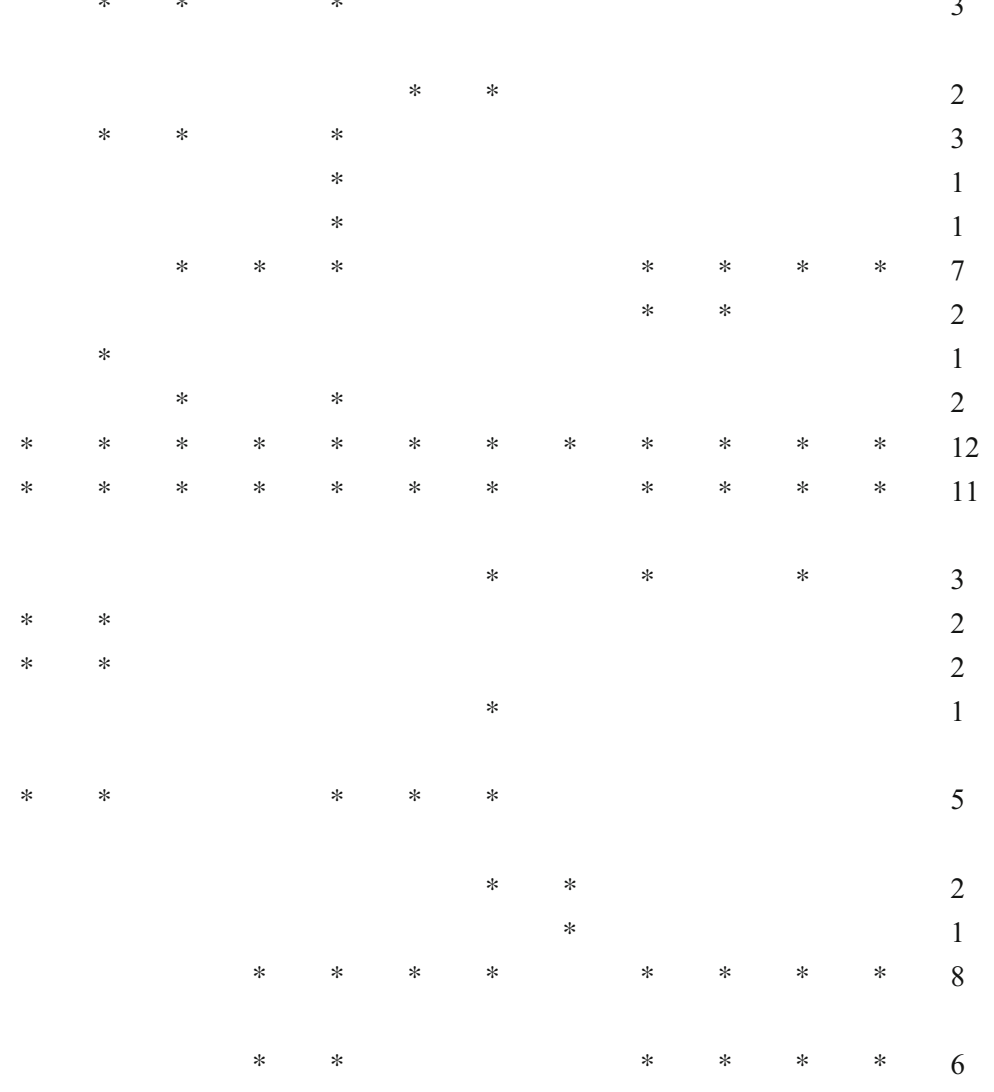

Bulla ampulla Linnaeus, 1758

Family Haminoeidae

Atys cylindrica (Helbling, 1779)

Atys sp.

Bakawan rotundata (Adams, 1850)

Family Scaphandridae

Scaphander bushirensis (Melvill and Standen, 1901)

Family Pyramidelloidea

Turbonilla sp.

Family Retusidae

Retusa sp.

$*$

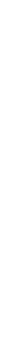

Tornatina $s p$

Scaphopoda

Family Dentaliidae

Dentalium octangulatum Donovan, 1804

Dentalium tomlini Melvill, 1918

Dentalium sp.

Family Laevidentaliidae

Laevidentalium curvotracheatum (Plate, 1908)

\section{Bivalvia}

Family Arcidae 
Table 3 (continued)

Species Station

$\begin{array}{lllllllllllll}1 & 2 & 3 & 4 & 5 & 6 & 7 & 8 & 9 & 10 & 11 & 12 & \text { Total }\end{array}$

Acar plicata (Dillwyn, 1817)

$*$

Family Glycymerididae

Brachidontes variabilis (Krauss, 1848)

Acrosterigma maculosa (Wood, 1815)

Fulvia australis (Sowerby, 1834)

Fulvia fragile (Forsskål, 1775)

Fulvia sp.

Laevicardium papyraceum (Bruguiere, 1792)

Solamen adamsianum (Melvill and Standen, 1907)

Family Pteriidae

Pinctada radiata (Leach, 1814)

Family Malleidae

Vulsella mytilina Lamarck, 1819

Vulsella sp.

Family Isognomonidae

Isognomon sp.

Family Lucinidae

Bellucian sp.

Family Isognomonidae

Isognomon sp.

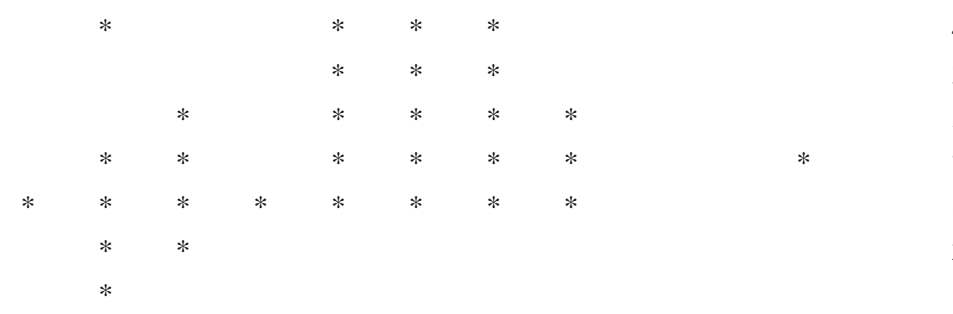

Family Lucinidae

Bellucian sp.

Bourdotia sp.

Divalinga arabica Dekker and Goud, 1994

Anodontia edentula (Linnaeus, 1758)

Rugalucina angela (Melvill, 1899)

Pillucina fischeriana (Melvill, 1899)

Pillucina sp.

Cavilucina pamela (Melvill and Standen, 1907)

Cavilucina sp.

Lucina sp.

Family Ungulinidae

Diplodonta holosphaera Melvill, 1899

Transkeia raveyensis (Sturany, 1899)

Diplodonta sp.

Carditopsis majeeda (Biggs, 1970)

Chama asperella Lamarck, 1819

Chama jukesii Reeve, 1847

Chama pacifica Broderip, 1835

Chama sp.

Family Cardiidae

Microcardium sp.

Family Tellinidae

Serratina capsoidae (Lamarck, 1818)

Tellina nitens Deshayes, 1855

Tellina sp.

Tellinella sp.

Tellidora sp.

Family Veneridae 
Table 3 (continued)

\begin{tabular}{|c|c|c|c|c|c|c|c|c|c|c|c|c|c|}
\hline Species Station & 1 & 2 & 3 & 4 & 5 & 6 & 7 & 8 & 9 & 10 & 11 & 12 & Total \\
\hline Callista florida (Lamarck, 1818) & & $*$ & & & & & $*$ & & & & & & 2 \\
\hline Callista sp. & & & & & & & $*$ & * & & & & & 2 \\
\hline Pinguitellina pinguis (Hanley, 1844) & & $*$ & * & & & & & & & & & & 2 \\
\hline Timoclea arakana (Nevill and Nevill, 1871) & & & & & * & $*$ & $*$ & $*$ & & & & & 4 \\
\hline Dosinia ceylonica (Dunker, 1865) & & & & $*$ & & & & & & & & & 1 \\
\hline Dosinia cntracta (Philippi, 1844) & & $*$ & & & & & & & & & & & 1 \\
\hline Dosinia sp. & & $*$ & & $*$ & & & $*$ & & & & & & 3 \\
\hline Circe sp. & & & & & & & $*$ & & & & & & 1 \\
\hline Gafrarium sp. & & $*$ & & & & & & & & & & & 1 \\
\hline \multicolumn{14}{|l|}{ Family Mactridae } \\
\hline Mactra sp. & & & & & & & $*$ & & & & & & 1 \\
\hline Total Gastropoda & 30 & 33 & 26 & 14 & 23 & 15 & 27 & 8 & 14 & 21 & 16 & 14 & \\
\hline Total Scaphopoda & 1 & 4 & 3 & 2 & 0 & 0 & 0 & 0 & 0 & 1 & 0 & 1 & \\
\hline Total Bivalvia & 15 & 26 & 22 & 11 & 11 & 15 & 25 & 10 & 4 & 6 & 7 & 5 & \\
\hline
\end{tabular}

different during winter and summer. Similarly, salinity is significantly different during winter and summer as well as winter and spring. If we refer to the locations (Table 4), we find that Al Mafyar is significantly different with respect to (w.r.t) temperature, and Dawhat is significantly different w.r.t salinity as well as species. The $k$-dominance curve (Fig. 6) suggests that in August (representing the summer), the least species richness was harboured at Dawhat Zekreet, while at Al Dhakhira the number is high in the same season. At Al Mafyar, very less seasonal variation is noticed; considering the cumulative diversity of all the seasons, Dawhat Zekreet showed the lowest, while Al Dhakhira had the highest species number (Fig. 6).

\section{Species Diversity}

Mean species number varied seasonally between the stations (Fig. 7). The maximum species number (43) was reported at a station in Al Dhakhira and the minimum number (6) at a station in Dawhat Zekreet in winter. The highest species number (10.4) was present at Al Dhakhira during January and the lowest (1.9) at Dawhat Zekreet during April. Overall, high evenness $\left(J^{\prime}\right)$ was recorded for all the seasons, but the highest (0.98) was during January for all the three locations, while the lowest (0.93) was during October at Dawhat Zekreet. The Shannon-Wiener and Simpson indices varied in time and space (Fig. 7). The maximum value of Shannon-Wiener's index $\left(H^{\prime}\right)$ was noted at Al Dhakhira in winter $\left(H^{\prime}=3.72\right)$ and the minimum for Dawhat Zekreet in spring $\left(H^{\prime}=1.74\right)$. Similar trends were observed for Simpson's Index (D): maximum $\mathrm{D}=0.99$ at Al Dhakhira in winter, and the minimum $\mathrm{D}=0.88$ at Dawhat Zekreet in spring. Overall, the diversity reduced in April at Dawhat Zakreet while at Al Dhakhira it reduced in August, and at other locations across the seasons showed minor variation. Overall indices reveal Dawhat Zakreet to be a low diversity habitat, while Al Dhakhira supports high diversity, especially in winter.

SIMPER analysis (Table 5) revealed that Dawhat Zekreet had dissimilar community when compared to Al Dhakhira (59\%) and Al Mafyar (67\%), probably due to absence of mangroves. Thus, on an average $37 \%$ of the community is shared between all three habitats but still a significant percentile remains dissimilar therefore making a contribution in distinction of sites. The community composition at each site showed marked relationship, and hence, clustered together (Fig. 8). In Redundancy analysis (RDA) analysis (Fig. 9) also, they were considered as response variables as they were influenced by hydro-chemical parameters, i.e., explanatory variables at each site. The most influential parameters correlated with the community at $\mathrm{Al}$ Mafyar were temperature and $\mathrm{pH}$, while at Al Dhakhira, Chlorophyll a was most influential and at Dawhat Zekreet, salinity (Fig. 9).

\section{Discussion}

The three sites chosen for the present study exhibit distinct habitats. Al Dhakhira is influenced by an old growth natural mangrove habitat, densely populated by A. marina; Al Mafyar is influenced by a recent plantation of $A$. marina; Dawhat Zekreet is free of any mangroves. The molluscan fauna showed distinct distributions at these three sites as seen from the diversity measure (Fig. 8). Moreover, the temporal and spatial distribution of molluscs also vary according to physico-chemical parameters, type of sediment, and productivity of the region (Jones 1986). Such high temperature or 


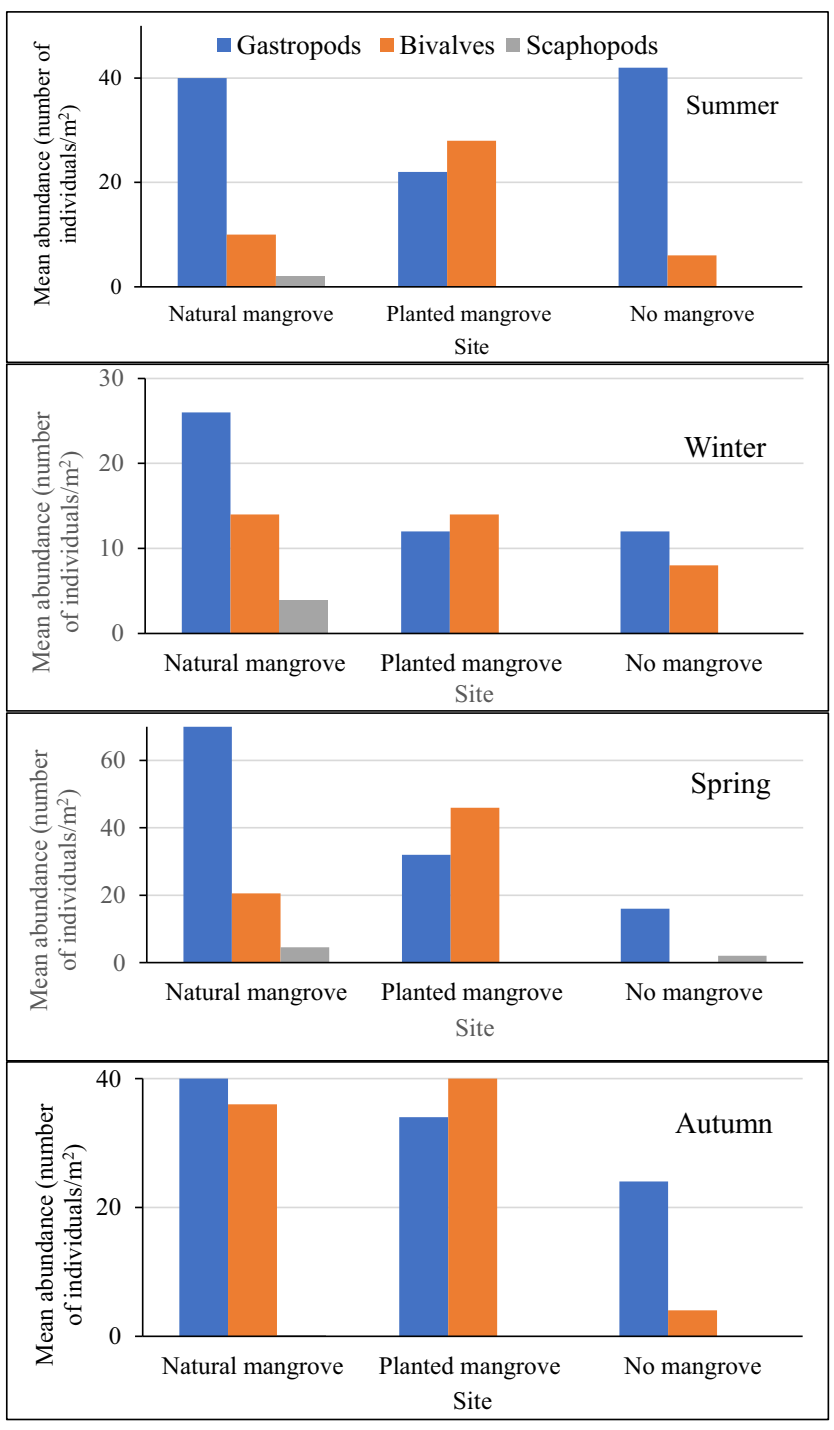

Fig. 3 Seasonal variations in abundance number of three major groups of molluscs. Each bar represents the mean abundance of mollusc species at three different sites

salinity variation is unlikely in the open ocean or coastal waters, but in isolated areas of the Arabian Gulf such as Dawhat Zekreet that are shallow and are exposed to high evaporation, such temperature and salinity variation is expected. The regionally high seasonality in salinity and sea surface temperature (SST) is reflected in species abundance as well. From the results of RDA analysis (Fig. 9), it is very evident that communities were influenced by temperature and salinity. However, species variation was significant only with location. We hypothesize that temperature and salinity play a less significant role compared to habitat characteristics such as existence of mangroves, which influences grain size and sedimentary organic matter. Mangroves appear to play a significant role in structuring the molluscan community, despite salinity and temperature showing high variation.
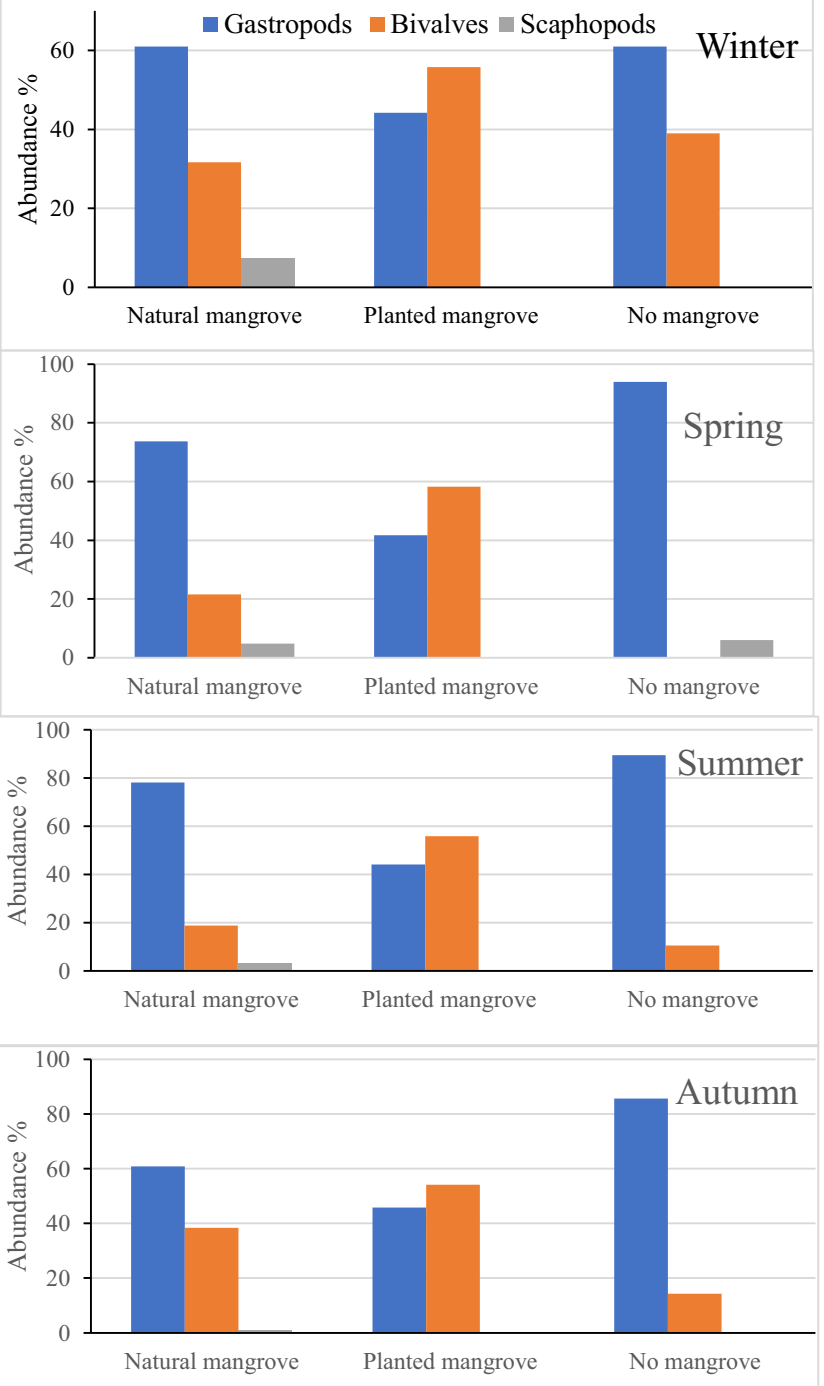

Fig. 4 Seasonal variation in the abundance (percentage) of molluscs at 3 sites of Qatar coast. Sites are as follows: natural mangrove (Al Dhakhira), planted mangrove (Al Mafyar) and no mangrove (Dawhat Zekreet)

These sites have high molluscan diversity compared to many mangrove habitats from other regions (Satheeshkumar and Khan 2012) and arid intertidal zones (El-Sorogy et al. 2016). The present molluscan community is predominantly representative of sandy habitat, and sediment grain size has been identified as one of the major factors for the molluscan diversity (Glémarec and Hily 1981; Dauvin et al. 2004).

Spring and summer are known to be periods of increased mollusc diversity and abundance in the Mediterranean region (Koulouri et al. 2006), and the present results show similar trends in the khors around Qatar as well. Spring was indeed a season showing high abundance of molluscs (Figs. 3 and 4). All the three sites had distinct differences in species abundance in every season (Fig. 8) except Al Mafyar, which had very similar faunal composition during summer and autumn. Mangroves also influence faunal diversity significantly (AlKhayat and Jones 1999). Al Dhakhira demonstrated the 
Al Dhakira

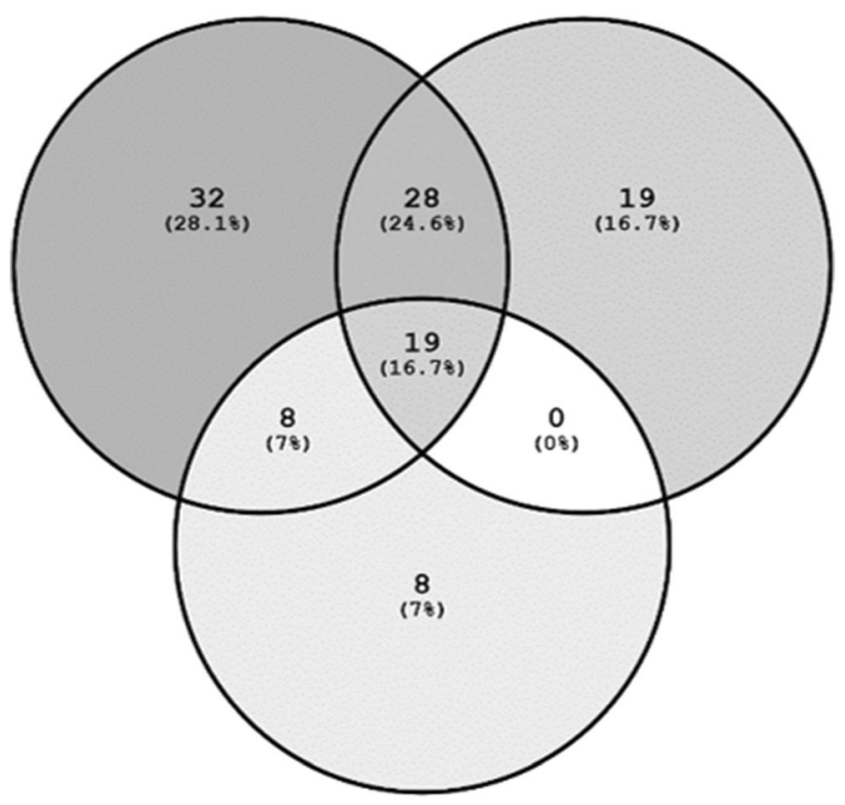

Dawat Zekreet

Fig. 5 Molluscan species common between and within the three sites

highest species richness (32), clearly indicating the influence of long present natural mangroves. Interestingly, Dawhat Zekreet did not share any common species with Al Mafyar, but shared 8 species with Al Dhakhira.

Tukey's pairwise comparison (Table 4) shows that variation was insignificant between Al Dhakhira and Al Mafyar, but, significant between Dawhat Zekreet and Al Dhakhira, and also between Dawhat Zekreet and Al Mafyar. Mangrove vegetation is present at both Al Dhakhira and Al Mafyar locations, and not at Dawhat Zekreet. As the khors are nearshore bays with insignificant circulation and no freshwater input, salinity variation is a function of evaporation (due to high temperature) as well as localised influence of mangrove canopy, which is also pivotal in regulating evaporation, and thus structuring the molluscan distribution.
The species number of the northern coast of Qatar can be compared with that of European coast (Koulouri et al. 2006; Lourido et al. 2008) and southern Mediterranean seas (Antit et al. 2016). Heterogeneous habitat plays an important role in enhancing the molluscan diversity, primarily hard substrate with sediment and algae (Antit et al. 2016; Turner and Kendall 1999). Al Dhakhira was most diverse in terms of species number, and it shared 28 species in common with $\mathrm{Al}$ Mafyar. Dawhat Zekreet was distinct from the two mangroveinfluenced areas.

Mangrove vegetation traps and re-mineralises considerable organic matter and detritus, resulting in high molluscan diversity (Moore et al. 2004), especially of detritivorous species. These three sites have been reported (Al-Khayat and AlKhayat 2000) to have a gradient of higher organic carbon and higher silt percentage in natural mangroves (Al Dhakhira) and least in the barren salt marsh (Dawhat Zekreet). The present study shows that the two mangrove areas were dominated by detritivorous gastropod Cerithium sp., followed by $P$. cingulata and C. rueppelli (Table 3). Bivalves, which are mostly filter feeders, are productive in khors; $F$. fragilis was the dominant bivalve within all the three locations. Notably, Al Mafyar site was dominated by bivalves, irrespective of seasons, which suggests the role of hydrodynamics in bringing the flux of organic matter from productive areas and mangroves acting as sinks (Lacerda et al. 1995; Li et al. 2018). There is no organic matter input from the land to Mafyar; it is coming from the mangrove litter (foliage, branches and roots) as well as from the detritus of dead algae, seagrass and salt marshes, etc. brought by ocean currents. Human population density is high at Al Dhakhira compared to other two sites, and there is a sewage treatment plant also at Al Khor (very near to Al Dhakhira), from where the treated waste water is released into the coastal water.

Temperature is an important parameter governing the ecophysiology and reproduction of many invertebrates and structures the settlement of spat as well as dominance. Salinity is responsible for segregation of species assemblage (Bruyndoncx et al. 2002) with greater salinity resulting in high

Table 4 Means of temperature, salinity, and species for season, location, and interaction

\begin{tabular}{|c|c|c|c|c|c|c|c|c|c|c|c|c|}
\hline \multirow[t]{2}{*}{ Season } & \multicolumn{4}{|l|}{ Temp $\left({ }^{\circ} \mathrm{C}\right)$} & \multicolumn{4}{|l|}{ Salinity } & \multicolumn{4}{|c|}{ No. of species } \\
\hline & $\begin{array}{l}\mathrm{Al} \\
\text { Dhakhira }\end{array}$ & Al Mafyar & $\begin{array}{l}\text { Dawhat } \\
\text { Zekreet }\end{array}$ & Mean & $\begin{array}{l}\mathrm{Al} \\
\text { Dhakhira }\end{array}$ & Al Mafyar & $\begin{array}{l}\text { Dawhat } \\
\text { Zekreet }\end{array}$ & Mean & $\begin{array}{l}\text { Al Dh- } \\
\text { akhira }\end{array}$ & $\begin{array}{l}\text { Al } \\
\text { Mafyar }\end{array}$ & $\begin{array}{l}\text { Dawhat } \\
\text { Zekreet }\end{array}$ & Mean \\
\hline Winter & $22.2650^{\mathrm{g}}$ & $22.2225^{\mathrm{g}}$ & $20.4825^{\mathrm{h}}$ & $21.6567^{\mathrm{c}}$ & $41.6150^{\mathrm{f}}$ & $42.3675^{\mathrm{e}, \mathrm{f}}$ & $51.7125^{\mathrm{c}}$ & $45.2317^{\mathrm{c}}$ & $18.50^{\mathrm{a}}$ & $10.75^{\mathrm{a}, \mathrm{b}}$ & $07.25^{\mathrm{a}, \mathrm{b}}$ & $12.17^{\mathrm{a}}$ \\
\hline Spring & $31.0250^{\mathrm{c}, \mathrm{d}}$ & $30.6100^{\mathrm{d}, \mathrm{e}}$ & $30.3050^{\mathrm{d}, \mathrm{e}}$ & $30.6467^{b}$ & $44.0475^{\mathrm{d}}$ & $43.5425^{\mathrm{d}, \mathrm{e}}$ & $55.3175^{\mathrm{b}}$ & $47.6358^{\mathrm{b}}$ & $17.75^{\mathrm{a}}$ & $11.00^{\mathrm{a}, \mathrm{b}}$ & $05.25^{\mathrm{b}}$ & $11.33^{\mathrm{a}}$ \\
\hline Summer & $33.4000^{\mathrm{b}}$ & $35.3000^{\mathrm{a}}$ & $34.6000^{\mathrm{a}}$ & $34.4333^{\mathrm{a}}$ & $44.4500^{\mathrm{d}}$ & $44.0750^{\mathrm{d}}$ & $58.0750^{\mathrm{a}}$ & $48.8667^{\mathrm{a}}$ & $08.00^{\mathrm{a}, \mathrm{b}}$ & $10.50^{\mathrm{a}, \mathrm{b}}$ & $09.25^{\mathrm{a}, \mathrm{b}}$ & $09.25^{\mathrm{a}}$ \\
\hline Autumn & $29.4750^{\mathrm{f}}$ & $30.2550^{\mathrm{e}}$ & $31.6250^{\mathrm{c}}$ & $30.4517^{\mathrm{b}}$ & $44.7125^{\mathrm{d}}$ & $44.6700^{\mathrm{d}}$ & $58.0350^{\mathrm{a}}$ & $49.1392^{\mathrm{a}}$ & $15.50^{\mathrm{a}, \mathrm{b}}$ & $11.50^{\mathrm{a}, \mathrm{b}}$ & $04.75^{\mathrm{b}}$ & $10.58^{\mathrm{a}}$ \\
\hline Mean & $29.0412^{\mathrm{b}}$ & $29.5969^{\mathrm{a}}$ & $29.2531^{\mathrm{b}}$ & & $43.7062^{\mathrm{b}}$ & $43.6637^{\mathrm{b}}$ & $55.7850^{\mathrm{a}}$ & & $14.94^{\mathrm{a}}$ & $10.94^{\mathrm{a}}$ & $06.62^{\mathrm{b}}$ & \\
\hline
\end{tabular}



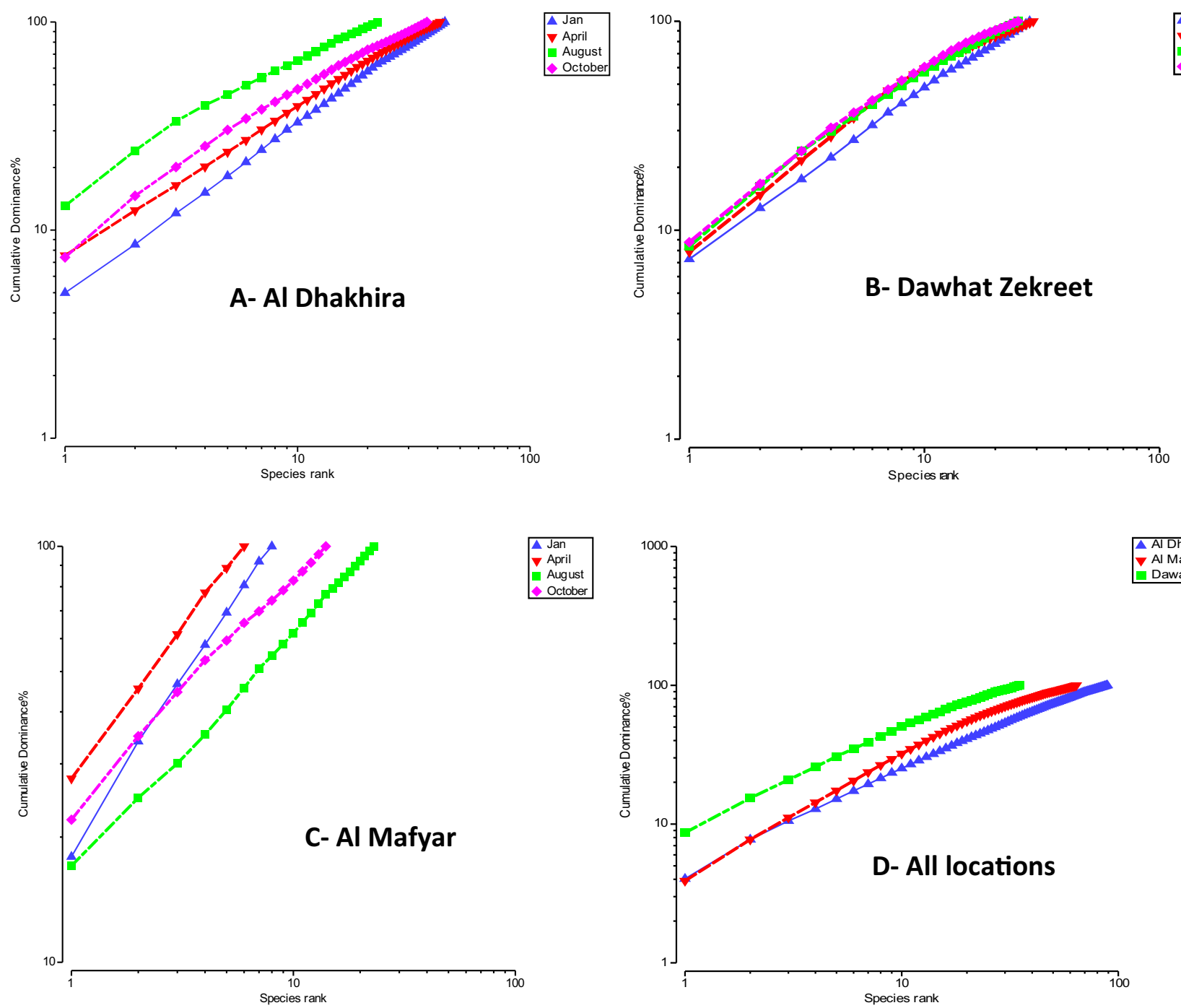

Fig. $6 \mathrm{~K}$-dominance curve comparing community change during each season at the three locations and cumulative (season) inter-site comparison (D)

diversity of molluses while very low salinity favours abundance (McKeon et al. 2015). Habitats such as mangroves govern grain size, organic matter, other physico-chemical parameters, thus playing a vital role in modulating the micro-climate and structuring the molluscan community (Davis et al. 2017). The diversity indices (Fig. 7) confirm the distinction between mangrove-influenced areas and the low diversity at Dawhat Zekreet, where the diversity increased during the summer with a completely different species composition. Differences in species composition and structure of the molluscan community might be due to human disturbances, degree of exposure, and/or substrate instability (Rahman and Barkati 2012). Probably, the high temperature and high salinity favoured a few species to increase in number.

There is no appreciable change in the mangrove forest or the environment at 2 sites, namely, Al Mafyar and Dawhat Zekreet between 2009 and 2020, compared to that at $\mathrm{Al}$ Dhakhira as seen in the satellite images (Fig. 1b). At Al
Dhakhira, while deepening the navigational channel, dredged materials were dumped on the site, thereby inhibited the growth of mangrove seedlings. Moreover, while developing a corniche (beach) at Al Dhakhira, even the grown mangroves were removed. These results strongly suggest that even the subtidal area is influenced by mangroves, which increase the diversity of molluscs compared to the no-vegetation site. Mangroves trap the organic matter and make it available for the detritivores, and this becomes critical to the molluscan community especially in this region, which has no riverine input or rainfall. There are shipping facilities and oil refineries located at Ras Laffan, near Al Dhakhira. Such facilities are installed at Dukhan as well, very near to Dawhat Zakreet. Therefore, we can expect the influence of oil pollution at these locations. This emphasizes the importance of mangroves and the need for their conservation and restoration, if molluscs are to be maintained. 

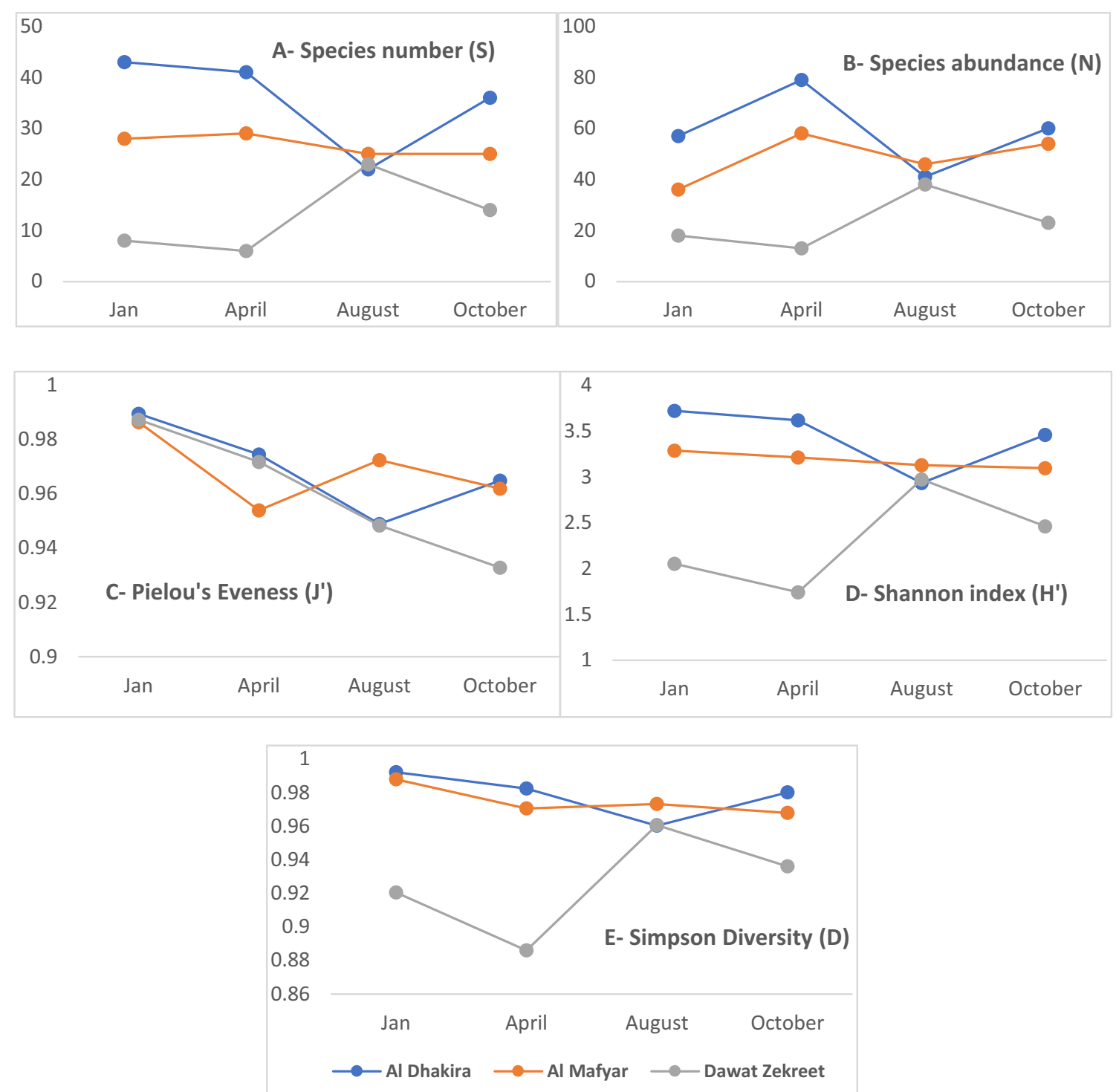

Fig. 7 Species diversity indices at each habitat (Al Dhakhira; Al Mafyar; Dawhat Zekreet) showing seasonal variation

\section{Conclusions}

Diversity of molluscan fauna in Qatar is significantly influenced by mangroves in the khors. There is also significant seasonality in species diversity and change in community driven by temperature and salinity. The k-dominance curve and the high species evenness suggest that the study area requires comprehensive sampling in the future as the species number saturation is yet to be achieved. The data and field visits reveal the absence of a few expected species, which may be indicators of direct or indirect anthropogenic stresses. The absence of large sized gastropods such as Cassidae, Volutidae, and Fasciolariidae might be because of over-exploitation due to fishing activities. Though some mangrove regions have been utilized for developmental activities, the Qatari government is concerned about the potential of mangrove vegetation, and hence initiated the program of planting of mangroves at several regions (for example, Al Mafyar and Fuwairit). As
Table 5 SIMPER Analysis based on Bray-Curtis Similarity Matrix (at $90 \%$ significance) between the sites

\section{Sites}

Average dissimilarity

Al Dhakhira (Natural mangroves) \& Al Mafyar (Planted mangroves)

52.94

Al Dhakhira (Natural mangroves) \& Dawhat Zekreet (No mangroves)

58.85

Al Mafyar (Planted mangroves) \& Dawhat Zekreet (No mangroves)
66.66 


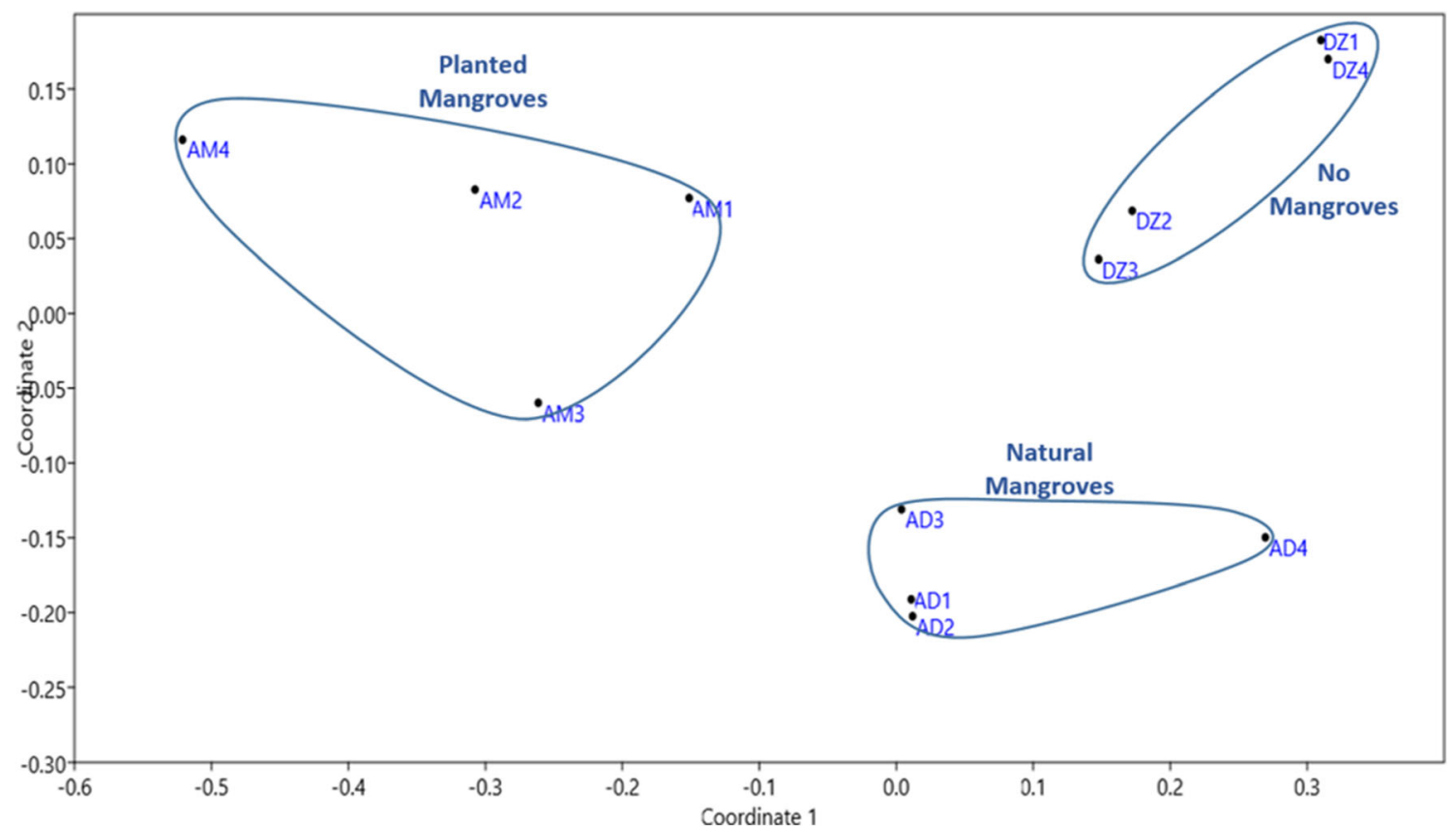

Fig. 8 Non-metric multidimensional scaling (NMDS) based on Bray-Curtis similarity clustered site-wise (Station AM1 to 4: Al Mafyar; AD1 to 4: Al Dhakhira and DZ1 to 4: Dawhat Zekreet). Closer stations on both the ordination space indicate similar community

mangrove is critical habitat for fisheries, and food security is one of the national priorities of Qatar, planting mangroves is a good solution for this purpose. Any serious stress on the mangrove habitat ecosystems may further lead to the disappearance or loss of natural or planted mangrove biota in the near future. It is expected that molluscan diversity will evolve in planted mangroves with time. Conservation and protection of mangrove swamps remain the first priority, as it forms one of the important and essential habitats for diverse marine and terrestrial species in Qatar, as well as part of the natural parks. Mangrove swamps are an exceptional area of biodiversity especially in barren and arid regions such as Qatar.
Fig. 9 Redundancy analysis (RDA) showing significant relationship between community at sites (response variables) and hydrochemical parameters (explanatory variables). Station AM1 to 4: Al Mafyar; AD1 to 4: Al Dhakhira and DZ1 to 4: Dawhat Zekreet

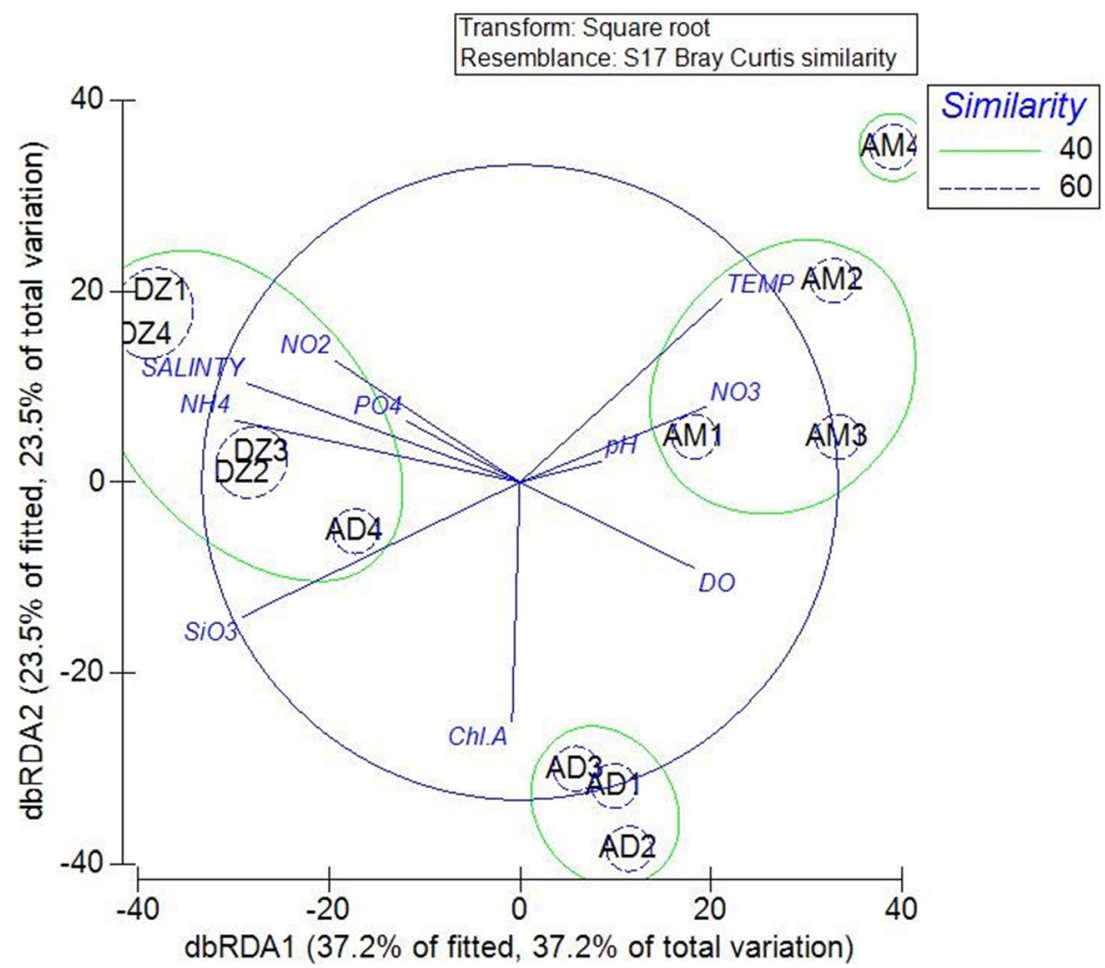


Acknowledgements We thank Dr. Talaat Abdel-Fattah Ahmad, Associate Professor of Environmental Science Center, Qatar University for helping in the Minitab statistics. Part of this work has been completed under the QU-NIO joint IRCC project (No. IRCC-2019-002).

Availability of Data and Materials Data are available with the corresponding author, and will be provided upon reasonable request.

\section{Code Availability Not applicable.}

Authors' Contributions Jassim A. Al-Khayat: Conceptualization, Methodology, Investigation, Visualization, Writing original draft; P. Vethamony: Writing review and editing, Supervision, Funding acquisition; Mandar Nanajkar: Methodology, Writing review and editing. The author(s) read and approved the final manuscript.

Funding Open access funding provided by the Qatar National Library. Part of this work has been supported by the QU-NIO joint IRCC project (No. IRCC-2019-002).

\section{Declarations}

Conflict of Interest/ Competing Interests There is no conflict of interest / competing interest.

Ethics Approval Not applicable.

Consent to Participate All authors gave their consent to participate.

Consent for Publication All authors gave their consent to publish this work in Wetlands.

Open Access This article is licensed under a Creative Commons Attribution 4.0 International License, which permits use, sharing, adaptation, distribution and reproduction in any medium or format, as long as you give appropriate credit to the original author(s) and the source, provide a link to the Creative Commons licence, and indicate if changes were made. The images or other third party material in this article are included in the article's Creative Commons licence, unless indicated otherwise in a credit line to the material. If material is not included in the article's Creative Commons licence and your intended use is not permitted by statutory regulation or exceeds the permitted use, you will need to obtain permission directly from the copyright holder. To view a copy of this licence, visit http://creativecommons.org/licenses/by/4.0/.

\section{References}

Al-Khayat JA (1997) The marine Mollusca of the Qatari waters, Arabian gulf. Qatar Univ Sci Bul 17:479-491

Al-Khayat JA (2005) Some macrobenthic invertebrates in the Qatari waters, Arabian gulf. Qatar Univ Sci J 25:126-136

Al-Khayat JA (2010) First record of five terrestrial snails in the State of Qatar. Turkish J Zool 34:539-545

Al-Khayat JA, Abdulla MA, Alatalo JM (2019) Three decades after compensatory planting of mangrove, diversity of benthic macrofauna at afforested and natural mangrove sites in Qatar no longer differs. Aquatic Sci 81:4

Al-Khayat JA, Al-Khayat FA (2000) Study of macrobenthic invertebrates in the Qatari waters, Arabian gulf. Bull Natl Institute Oceanography Fisher 26:125-148
Al-Khayat JA, Balakrishnan P (2014) Avicennia marina around Qatar: tree, seedling and pneumatophore densities in natural and planted mangroves using remote sensing. Int J Sci 3:18-27

Al-Khayat JA, Jones DA (1999) A comparison of the macrofauna of natural and planted mangroves in Qatar. Estuarine Coastal Shelf Sci 49:55-63

Al-Yamani F, Boltachova N, Revkov N, Makarov M, Grintsov V, Kolesnikove E, Murina V (2009) Winter species composition diversity and abundance of macrozoobenthos in Kuwait's waters, Arabian gulf. ZooKeys 31:17-38

Anbiah R (2007) Molluscs. In: Al Abdessalaam TZ (ed) Marine environment and resources of Abu Dhabi. Motivate Publishing, Dubai, pp 108-117

Antit M, Daoulatli A, Urra J, Rueda J, Gofas S, Salas C (2016) Seasonality and trophic diversity in Molluscan assemblages from the bay of Tunis (southern Mediterranean Sea). Mediterranean Marine Sci 17:692-707

Basson PW, Burchard JE, Hardy JT, Price A (1977) Biotopes of the western Arabian gulf: marine life and environments of Saudi Arabia. Aramco department of loss prevention and environmental affairs publisher, Saudi Arabia

Bosch D, Bosch E (1989) Sea shells of southern Arabia. Motivate Publishing, London

Bosch DT, Dance SP, Moolenbeek RG, Oliver PG (1995) Seashells of eastern Arabia. Motivate Publishing, London

Bresler V, Mokady O, Fishelson L, Feldstein T, Abelson A (2003) Marine Molluscs in environmental monitoring. Helgoland Marine Res 57:157-165

Bruyndoncx L, Jordaens K, Ysebaert T, Meire P, Backeljau T (2002) Molluscan diversity in tidal marshes along the Scheldt estuary. Hydrobiologia 474(189-196):189-196

Carroll ML, Johnson BJ, Henkes GA, McMahon KW, Voronkov A, Ambrose WG Jr, Denisenko SG (2009) Bivalves as indicators of environmental variation and potential anthropogenic impacts in the southern Barents Sea. Marine Pollut Bull 59:193-206

Chakraborty P (2017) Oyster reef restoration in controlling coastal pollution around India: a viewpoint. Marine Pollut Bull 115:190-193

Chakraborty P, Ramteke D, Gadi SD, Bardhan P (2016) Linkage between speciation of cd in mangrove sediment and its bioaccumulation in total soft tissue of oyster from the west coast of India. Marine Poll Bull 106:274-282

Dauvin JC, Thiebaut E, Gomez Gesteira JL, Ghertsos K, Gentil F, Ropert M, Sylvand B, Thiébaut E (2004) Spatial structure of a subtidal microbenthic community in the bay of Veys (western bay of seine, English Channel). J Exper Marine Biol Ecol 307:217-235

Davis SE, Childers DL, Day JW, Rudnick DT, Sklar FH (2001) Nutrient dynamics in vegetated and unvegetated areas of a southern Everglades mangrove creek. Estuarine Coastal Shelf Sci 52:753-768

Davis TR, Harasti D, Kelaher B, Smith SDA (2017) Spatial and temporal variation in subtidal molluscan diversity amongst temperate estuarine habitats. Marine Ecol 38:e12428

Edgar GJ (1990) The influence of plant structure on the species richness, biomass and secondary production of macrofaunal assemblages associated with Western Australian seagrass beds. J Exper Marine Biol Ecol 137:215-240

Elder JF, Collins JJ (1991) Freshwater Molluses as indicators of bioavailability and toxicity of metals in surface-water systems. Rev Environ Contamination Toxicol 122:37-79

El-Ghazaly G, Abdel-Razik M (1993) Propagation and transplantation of the mangrove Avicennia marina within the State of Qatar, Research Report, Scientific and Applied Research Center, Qatar University, p 122

El-Sorogy AS, Tawfik M, Almadani SA, Attiah A (2016) Assessment of toxic metals in coastal sediments of the Rosetta area, Mediterranean Sea, Egypt. Environ Earth Sci 75:398

Emery KO (1956) Sediments and water of the Persian Gulf. Bull Am Assoc Petroleum Geol 40:2354-2383 
Feulner GR, Hornby RJ (2006) Intertidal Molluscs in UAE lagoons. Tribulus 16:17-23

Glémarec M, Hily C (1981) Perturbations apportees a la macrofaune benthique de la baie de Concarneau par les effluents urbains et portuaires. Acta Oecologica Acta Applicata 2:139-150

Green S (1994) Bahrain seashells. Arabian Printing and Publishing House, Bahrain

Halpern B, Walbridge S, Selkoe K, Kappel C, Micheli F, D'Agrosa C, Bruno J, Casey K, Ebert C, Fox H, Fujita R, Heinemann D, Lenihan H, Madin E, Perry M, Selig E, Spalding M, Steneck R, Watson R (2008) A global map of human impact on marine ecosystems. Science 31:948-995

Hatcher BG, Johannes RE, Robertson AI (1989) Review of research relevant to the conservation of shallow tropical marine ecosystems. Oceanography Marine Biol Annual Rev 27:337-414

Johns WE, Yao F, Olson DB, Josey SA, Grist JP, Smeed DA (2003) Observations of seasonal exchange through the straits of Hormuz and the inferred freshwater budgets of the Persian Gulf. J Geophys Res 108:3391

Jones DA (1986) A field guide to the seashores of Kuwait and the Arabian gulf. University of Kuwait, Kuwait

Jones DA, Richmond MD (1992) Intertidal and subtidal marine habitat surveys. In: Establishment of a marine habitat and wildlife sanctuary for the Gulf region. Final report for phase I. Jubail and Frankfurt, CEC/NCWCD, pp 134-161

Kabir M, Abolfathi M, Hajimoradloo A, Zahedi S, Kathiresan K, Goli S (2014) Effect of mangroves on distribution, diversity and abundance of Molluscs in mangrove ecosystem: a review. Aquaculture Aquarium Conservation Legislation Int J Bioflux Soc 7:286-300

Koch V, Wolff M (1996) The mangrove snail Thais kiosquiformis Duclos: a case of life history adaptation to an extreme environment. J Shellfish Res 8:421-432

Kohan A, Zahra B, Mohammadreza S (2012) The gastropod fauna along the Bushehr province intertidal zone of the Persian Gulf. J Persian Gulf 3:33-42

Koulouri P, Dounas C, Arvanitidis C, Koutsoubas D, Eleftheriou A (2006) Molluscan diversity along a Mediterranean soft bottom sublittoral ecotone. Scientia Marina 70:573-583

Lacerda LD, Ittekkot V, Patchineelam SR (1995) Biogeochemistry of mangrove soil organic matter: a comparison between Rhizophora and Avicennia soils in South-Eastern Brazil. Estuarine, Coastal Shelf Sci 40(6):713-720

Levings SC, Garrity SD, Burns KA (1994) The Galeta oil spill. III. Chronic reoiling, long-term toxicity of hydrocarbon residues and effects on epibiota in the mangrove fringe. Estuarine Coastal Shelf Sci 38:365-395

Li SB, Chen PH, Huang JS, Hsueh ML, Hsieh LY, Lee CL, Lin HJ (2018) Factors regulating carbon sinks in mangrove ecosystems. Global Change Biology 24(9):4195-4210. https://doi.org/10.1111/ gcb. 14322

Lourido A, Cacabelos E, Troncoso JS (2008) Patterns of distribution of the polychaete fauna in subtidal soft sediments of the Ría de Aldán (North-Western Spain). J Marine Biological Assoc United Kingdom 88:263-275

McCain JC (1984a) Marine ecology of Saudi Arabia. The intertidal fauna of sand beaches in the northern area, Arabian gulf, Saudi Arabia. Fauna Saudi Arabia 6:53-78

McCain JC (1984b) Marine ecology of Saudi Arabia. The nearshore soft benthic communities of the northern area, Arabian gulf. Fauna Saudi Arabia 6:79-101
McKeon CS, Tunberg BG, Johnston CA, Barshis DJ (2015) Ecological drivers and habitat associations of estuarine bivalves. Peer J 3: e1348. https://doi.org/10.7717/peerj.1348

Mohammed SZ, Al-Khayat JA (1994) A preliminary check- list of benthic Mollusca on the Qatari coasts, Arabian gulf. Qatar Univ Sci J 14:201-206

Moore AM, Arango HG, Di Lorenzo E, Cornuelle BD, Miller AJ, Neilson DJ (2004) A Comprehensive Ocean prediction and analysis system based on the tangent linear and adjoint components of a regional ocean model. Ocean Modelling 7:227-258

Morris S, Morris N (1993) New shells from the UAE's east coast. Tribulus 3:5-8

Oliver PG (1992) The bivalve seashells of the Red Sea. An Identification Guide. Christa Hemmen, Verlag and The National Museum of Wales, Cardiff

Parker LM, Ross PM, O’Connor WA, Pörtner HO, Scanes E, Wright JM (2013) Predicting the response of molluscs to the impact of ocean acidification. Biology (Basel) 2:651-692

Parsons TR, Maita Y, Lalli CM (1984) A manual of chemical and biological methods for seawater analysis. Pergamon Press, United Kingdom

Pous S, Lazure P, Carton X (2015) A model of the general circulation in the Persian Gulf and in the strait of Hormuz: Intraseasonal to interannual variability. Continental Shelf Research 94:55-70

Prasad TG, Ikeda M, Kumar SP (2001) Seasonal spreading of the Persian Gulf water mass in the Arabian Sea. Journal of Geophysical Research 106:17059-17071

Price A (2002) Simultaneous hotspots and cold spots of marine biodiversity and implications for global conservation. Marine Ecology Progress Series 241:23-27

Price A, Sheppard C, Roberts C (1993) The Gulf: its biological setting. Marine Pollution Bulletin 27:9-15

Privett DW (1959) Monthly charts of evaporation from the North Indian Ocean, including the Red Sea and the Persian Gulf. Quarterly Journal of the Royal Meteorological Society 85:424-428

Quigg A, Al-Ansi M, Al Din N, Wei L, Nunnally C, Al-Ansari I, Gilbert TR, Yousria S, Ibrahim AM, Ismail M et al (2013) Phytoplankton along the coastal shelf of an oligotrophic hypersaline environment in a semi-enclosed marginal sea: Qatar (Arabian gulf). Continental Shelf Research 60:1-16

Rahman S, Barkati S (2012) Spatial and temporal variations in the species composition and abundance of enthic Molluses along 4 rocky shores of Karachi. Turkish J Zool 36:291-306

Satheeshkumar P, Khan AB (2012) Identification of mangrove water quality by multivariate statistical analysis methods in Pondicherry coast, India. Environ Monitor Assess 184:3761-3774

Shanmugam A, Vairamani S (1999) Molluscs in mangroves: a case study. Galaxea 8:371-382

Shannon GE, Wiener WW (1963) The mathematical theory of communication. University of Illinois Press, Urbana

Sheppard C, Al-Husiani M, Al-Jamali F, Al-Yamani F, Baldwin R, Bishop J, Benzoni F, Dutrieux E, Dulvy N, Durvasula S, Jones D, Loughland R, Medio D, Nithyanandan M, Pilling G, Polikarpov I, Price A, Purkis S, Riegl B, Saburova M, Namin K, Taylor O, Wilson S, Zainal K (2010) The Gulf: a young sea in decline. Marine Pollut Bull 60:3-38

Smythe KR (1972) Marine Mollusca from Bahrain Island, Persian gulf. J Conchol 27:491-496

Smythe KR (1979) The marine Mollusca of the United Arab Emirates, Arabian gulf. J Conchol 30:57-80 
Smythe KR (1982) Seashells of the Arabian gulf. George Allen and Unwin, London

Swift SA, Bower AS (2003) Formation and circulation of dense water in the Persian Gulf. J Geophys Res 108:1-21

Törnroos A, Bonsdorff E, Bremner J, Blomqvist M, Josefson AB, Garcia C, Warzocha J (2015) Marine benthic ecological functioning over decreasing taxonomic richness. Journal of Sea Research 98:49-56

Towns DR (1979) Composition and zonation of benthic invertebrate communities in New Zealand Kuari forest stream. Freshwater Biol 9:251-260

Turner SJ, Kendall MA (1999) A comparison of vegetated and unvegetated soft-sediment macrobenthic communities in the river
Yealm, southwestern Britain. J Marine Biol Assoc United Kingdom 79:741-743

Van Lavieren H, Burt J, Feary DA, Cavalcante G, Marquis E, Benedetti L, Trick C, Kjerfve B, Sale PF (2011) Managing the growing impacts of development on fragile coastal and marine ecosystems: lessons from the Gulf. A policy report, UNU-INWEH, Hamilton Vine P (1986) Red Sea invertebrates. IMMEL Publishing, London

Publisher's Note Springer Nature remains neutral with regard to jurisdictional claims in published maps and institutional affiliations. 